\title{
Money, Political Ambition, and the Career Decisions of Politicians*
}

\author{
Michael P. Keane \\ ARC Federation Fellow, University of Technology Sydney \\ Research Professor, Arizona State University \\ Antonio Merlo \\ University of Pennsylvania \\ CEPR, CESifo and NBER
}

May 2007

Revised, February 2010

\begin{abstract}
In this paper we assess the impact of a variety of policies that may influence the career decisions of members of the U.S. Congress, using the empirical framework of Diermeier, Keane and Merlo (2005). These policies alter incentives to run for re-election, run for higher office or leave Congress, by altering wages, non-pecuniary rewards and career prospects (both in and out of Congress). We find that reducing the relative wage of politicians would substantially reduce the duration of congressional careers. Notably, however, the effect varies considerably across different types of politicians. A reduction in the congressional wage would disproportionately induce exit from Congress by "skilled" politicians, Democrats, and politicians who were relatively young when first elected. Interestingly, however, it would not cause the type of politicians who most value legislative accomplishments ("achievers") to disproportionately exit Congress. Thus, wage reductions would not reduce the "quality" composition of Congress in this sense. Term limits also have similar effects on achievers and non-achievers. However, we find that term limits would disproportionately induce members of the majority party to exit Congress. This has the interesting implication that term limits make it more difficult to sustain substantial congressional majorities over time. We do find three types of policies that disproportionately induce non-achievers to leave Congress: (i) elimination of seniority as a determinant of key committee assignments, (ii) restricting private sector employment after leaving Congress, and (iii) reducing the seniority advantage in elections. (JEL D72, J44, J45)
\end{abstract}

ADDRESS FOR CORRESPONDENCE: Antonio Merlo, Department of Economics, University of Pennsylvania, 3718 Locust Walk, Philadelphia, PA 19104. E-mail: merloa@econ.upenn.edu

* Financial support from National Science Foundation grants SBR-9730483 to Keane and Merlo and SES-0617901 to Merlo, and Australian Research Council grant FF0561843 to Keane are gratefully acknowledged. 


\section{Introduction}

Understanding the motivations of politicians, particularly the extent to which their career decisions are influenced by monetary incentives vs. political ambition - where the latter may take the form of lust for political power and the perks/prestige of office, or the more positive form of the desire for public service and/or legislative achievement - has long being of great interest to social scientists. In his famous 1918 lecture Politics as a Vocation, Max Weber writes:

“Politics, just as economic pursuits, may be a man's avocation or his vocation. [...] There are two ways of making politics one's vocation: Either one lives 'for' politics or one lives 'off' politics. [...] He who lives 'for' politics makes politics his life, in an internal sense. Either he enjoys the naked possession of the power he exerts, or he nourishes his inner balance and selffeeling by the consciousness that his life has meaning in the service of a 'cause.' [...] He who strives to make politics a permanent source of income lives 'off' politics as a vocation." [from Gerth and Mills (1946; pp. 83-84)]

Recently, political economists have begun to investigate how relative salaries in the political and private sectors affect behavior of politicians. For example, Besley (2004), Caselli and Morelli (2004) and Messner and Polborn (2004) model how wages of elected officials affect their average ability, in environments where ability is uni-dimensional (i.e., common to the political and private spheres). In Caselli and Morelli (2004), individuals with low ability have a lower opportunity cost of running, as they face worse opportunities in the private sector. In their framework, increasing the relative wage of elected officials increases the average ability of politicians. ${ }^{1}$ Similarly, in Messner and Polborn (2004), lower ability individuals are more likely to run for office in equilibrium. The mechanism is different, however. It relies on the fact that if salaries of elected officials are relatively low, high-ability individuals may free-ride by not running and letting low-ability types run instead. This implies a U-shaped relation between the salary of elected officials and their average ability. ${ }^{2}$

Mattozzi and Merlo (2008), on the other hand, propose a dynamic equilibrium model of the careers of politicians. Their model has two dimensions of ability, political skills and market ability. Individual endowments of each type of skill, which are private information, are positively correlated. In equilibrium, there are both career politicians (who work in politics until retirement) and people

\footnotetext{
${ }^{1}$ Besley (2004) obtains a similar result in a political agency model with moral hazard and adverse selection, and also provides some empirical evidence.

${ }^{2}$ While the probability that low-ability individuals run for office increases monotonically with the salary, for high-ability individuals it may decrease at relatively low levels of salary before it increases.
} 
with political careers (who eventually exit politics to enter the private sector). Career politicians enter the politics because of the non-pecuniary rewards from being in office, which include both ego rents and potential benefits from influencing policy. But individuals with political careers enter politics in order to increase their market wages. In equilibrium, individuals with political careers (i.e., those who eventually plan to leave politics to reap rewards in the private sector) have relatively better political skills than career politicians, although career politicians are still better than average.

Mattozzi and Merlo find that an increase in salaries in the political sector decreases the average quality of those who become politicians, but has an ambiguous effect on the average quality of career politicians. These results obtain because a higher salary in the political sector makes politics a more attractive option for all levels of political skills, thus lowering the quality of the marginal politician. At the same time, however, relatively better incumbent politicians are willing to remain in politics, since the salary in politics is now better relative to the market wages.

In this paper, we assess quantitatively how career decisions of politicians respond to changes in wages, and to a variety of other monetary and non-pecuniary incentives. The basis of our analysis is the paper by Diermeier, Keane and Merlo (2005) - henceforth, DKM - who develop a general framework for the empirical analysis of the costs and benefits of a career in the U.S. Congress. They specify a dynamic model of career decisions of members of Congress, and estimate it using a new data set that contains detailed information on all members of Congress in the post-war period. ${ }^{3}$

DKM validate their model in two ways: First, they show it provides an excellent fit to a wide range of behaviors of politicians. Second, they show that it gives reasonable estimates of the value of congressional seats; results that are in the ballpark of estimates obtained by Groseclose and Milyo (1999) who study a unique situation in 1992 when many House members had the one time chance to leave Congress for a "golden parachute" payment. As the DKM model gives reasonable results in these exercises, it seems credible to use it to predict the impact of various other policy changes.

Since we rely on the DKM model, it is important to discuss its structure and the data used to estimate it. A novel feature of the DKM data is that it incorporates information about postcongressional employment and salaries when members exit Congress, which allows estimation of the returns to congressional experience in post-congressional employment. They find that congressional

\footnotetext{
${ }^{3}$ The study of congressional careers has a long history (see Schlesinger (1966) and Hibbing (1991)). Recently, several authors studied representatives' choices among the three options: (i) run for reelection; (ii) run for higher office, or (iii) retire (see Groseclose and Krehbiel (1994), Groseclose and Milyo (1999), Hall and van Houweling (1995), Kiewiet and Zeng (1993)). These studies estimate static models that ignore such dynamic factors as how congressional experience affects post-congressional career prospects. The DKM model is the first to incorporate such dynamics.
} 
experience significantly increases post-congressional wages in the private sector. ${ }^{4}$ DKM's framework also allows one to estimate the relative importance of pecuniary and non-pecuniary returns to a career in Congress. They find that the non-pecuniary rewards are substantial (especially in the Senate). Also, using data on important legislative achievements by members of Congress compiled by Mayhew (2000), they relate part of these non-pecuniary rewards to the desire for policy accomplishments or political ambition, which they estimate to be rather large. ${ }^{5}$

An important aspect of the DKM framework is that it takes into account that the decision of a member of Congress to seek reelection depends not only on current payoffs, but also on the option value of holding the seat. This option value may depend, among other things, on the probability of being named to a committee, or winning a bid for higher office in the future (e.g., a member of the House may run for a seat in the Senate), as well as future career opportunities outside of Congress.

The DKM framework also distinguishes among "types" of politicians. Politicians differ both in observed characteristics (age, education, family background, party, prior political experience) and in unobserved or "latent" characteristics. The two latent characteristics are: (i) political skill, which means ability to win elections (i.e., politicians are either "skilled" or "unskilled"), and (ii) the desire for legislative accomplishment. DKM use Mayhew (2000)'s study of legislative accomplishments to categorize politicians as "achiever" and "non-achiever" types - i.e., those who value and are effective at realizing important legislative accomplishments vs. those who are not.

Here, we use the DKM model to quantify the potential effects of a range of hypothetical policies on the career decisions of members of Congress. Of central importance is the question of whether particular policies would impact the composition of Congress by differentially affecting incentives of different types of politicians. For instance, a policy that disproportionately induced achievers to leave Congress may be viewed as undesirable, ceteris paribus.

The policies we consider affect the incentives of members of Congress in different ways. They can be broadly classified into three groups depending on whether they affect: (i) future career prospects either inside or outside Congress; (ii) wages or other monetary rewards from serving in Congress; or (iii) chances of re-election to Congress. For example, the first group of policies

\footnotetext{
${ }^{4}$ Winning reelection to the House (Senate) for the first time increases post-congressional wages in the private sector by $4.4 \%(16.7 \%)$. However, this effect diminishes rapidly with additional experience: averaging over members' experience levels, the effect on post-congressional wages of an additional term in the House (Senate) is $2.4 \%(5.2 \%)$.

${ }^{5}$ General non-pecuniary rewards amount to over $\$ 200,000$ per year for a senator and about $\$ 30,000$ per year for a representative (in 1995 dollars). For comparison, the average annual salary of a member of Congress over the sample period 1947-1994 was $\$ 120,378$ (in 1995 dollars). In addition, the non-pecuniary rewards from important legislative accomplishments are about $\$ 350,000$ and $\$ 400,000$ for representatives and senators, respectively.
} 
includes altering prospects of being named to important committees, or forbidding politicians from working in the private sector after exiting Congress. The second group includes reductions in congressional wages or pensions. The third group includes term limits.

Aside from helping to quantify the importance of various factors in motivating politicians, we have also chosen experiments that have some policy relevance (or that are at least related to potentially relevant policies). Term limits, changes in congressional salaries, restrictions on activities that politicians may engage in after leaving office (i.e., lobbying activities), and policies to reduce seniority advantages (in being named to key committees or in running for re-election), are all policies that have been seriously considered. Thus, there is an actual policy interest in understanding how such policies would affect decisions of members of Congress.

Our main findings can be summarized as follows. First, the effect of reducing the relative wage of members of Congress is fairly sizeable. For example, a $20 \%$ reduction in the congressional wage leads to a $14 \%$ decrease in the average duration of congressional careers. Notably, however, the effect is not uniform across politicians of different types. A reduction in the congressional wage would disproportionately induce skilled politicians to exit Congress. The effect is also relatively large for Democrats and politicians who were relatively young when first elected to Congress.

However, a salary reduction does not cause the achiever type to disproportionately exit Congress. We would argue that whether a politician is the achiever type is perhaps a better measure of his/her "quality" than whether he/she is the "skilled" type (which refers to a politician's ability to win elections, or electability). Thus, referring to the theoretical papers on the impact of salary noted above, our conclusion is that salary does not differentially impact career decisions of high vs. low quality members of Congress.

Interestingly, we do find three types of policies that disproportionately induce non-achievers to leave (or achievers to stay) in the Congress. These are policies that: (i) eliminate seniority as a determinant of key committee assignments, (ii) restrict private sector employment after leaving Congress, or (iii) reduce the seniority advantage in elections. An example of (ii) would be restricting former members of Congress from working as lobbyists, while examples of (iii) would be various types of campaign finance reform that reduce fundraising advantages of incumbents.

Two other results are worth commenting on. First, we find that term limits would have similar effects on achievers and non-achievers. Thus, they would not help to improve the quality composition of Congress in this sense. Second, we find that term limits would disproportionately 
induce members of the majority party (Democrats during our sample period) to exit Congress. This has the interesting implication (to our knowledge not previously noted) that term limits would make it more difficult to sustain substantial congressional majorities over time.

Interestingly, DKM already considered the experiment of changing congressional wages. They concluded that this had little effect on the behavior of politicians, either in general or for specific types. We find their conclusions are invalid - it appears they were misled by looking at only a subset of the outcome measures we examine here. And DKM also considered term limits, but again, because they looked at fewer outcome measures and differentiated politicians less finely by type, they did not find the key result on party composition effects that we stress here. The other experiments we consider here are completely new.

The rest of the paper is organized as follows. Section 2 provides a brief summary of the DKM model and the data used to estimate it. Section 3 presents the results of our policy experiments. Section 4 summarizes our results and concludes.

\section{The Model and Data Set}

\subsection{Overview}

Following DKM, we model the career decisions of a member of Congress as the solution to a stochastic dynamic optimization problem with a finite horizon. Let $t=1, \ldots, T$ denote a generic decision period, where the length of a period is two years - the length of a House term - and $T$ is the terminal decision period after which an individual must exit Congress. ${ }^{6}$

To illustrate the basic features of the model, consider a sitting member of the U.S. House. At the end of the two-year House term, he/she must decide whether to run for reelection, run for a seat in the Senate (if available), retire from professional life, or leave Congress to pursue an alternative career. In order to solve this decision problem, the representative compares the expected present value of current and future payoffs associated with the different alternatives, being fully aware of the fact that current decisions will affect the distribution of future payoffs.

For example, if a politician decides to exit Congress and pursue an alternative career, he/she faces a distribution of potential post-congressional wages determined, in part, by his/her current stock of congressional experience. On the other hand, if the politician decides to run for reelection, and is succesful, then he/she remains in the House for two more years, collects the congressional

\footnotetext{
${ }^{6}$ Since the maximum duration of a congressional career is 50 years of service (Strom Thurmond served in the Senate for almost 50 years, from 1954 to 2003, when he died in office at the age of 100), we let $T=25$.
} 
wage along with any non-pecuniary payoffs from office, and faces a similar decision problem at the end of the next House term. The politician recognizes that this additional term in Congress may improve post-congressional employment prospects, and may enhance the probability of winning a future bid for higher office. At the same time, he/she also recognizes that running for reelection entails the possibility of losing, which may also affect future prospects outside Congress. The politician takes all these considerations into account when making the current decision.

To simplify the exposition of the model, it is useful to start by listing the state variables that are relevant to the decision problem of a member of Congress. Since in any given period $t$ a politician $i$ can either be in the House, in the Senate, or have exited Congress, as a compact notation we use $X H_{i t}, X S_{i t}$, and $X P_{i t}$ to denote the set of state variables relevant for the current decisions of representatives, senators, and ex-members of Congress, respectively. In particular, we have:

$$
\begin{aligned}
& X H_{i t}=\left(B A_{i}, J D_{i}, \text { Age }_{i t}, \text { Party }_{i}, T H_{i t}, T S_{i t}, C O M_{i t}, \text { Skill }_{i}, \text { Achieve }_{i},\right. \\
& \left.S O D_{i}, S O S_{i t}, S O W_{t}, \text { Scandal }_{i t}, \operatorname{Re} d_{i s t}, E S_{i t}, \text { Cycle }_{i t}, I N C_{i t}, \text { Cohort }_{i}\right) \text {, } \\
& X S_{i t}=\left(B A_{i}, J D_{i}, \text { Age }_{i t}, \text { Party }_{i}, T H_{i t}, T S_{i t}, C O M_{i t}, \text { Skill }_{i}, \text { Achieve }_{i}\right. \text {, } \\
& \left.S_{i t}, S O W_{t}, \text { Scandal }_{i t}, S T_{i t}, \text { Cohort }_{i}\right) \text {, } \\
& X P_{i t}=\left(B A_{i}, J D_{i}, A e_{i t}, T H_{i t}, T S_{i t}, C O M_{i t}, V E_{i t}, S k i l l_{i}\right) .
\end{aligned}
$$

Here, $B A_{i}$ and $J D_{i}$ are dummies for whether politician $i$ has a BA or a JD degree. Along with age,

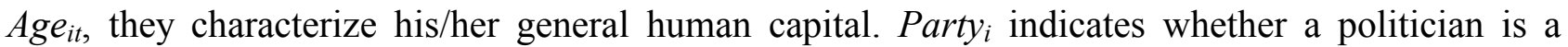
Democrat or a Republican. $T H_{i t}, T S_{i t}$, and $C O M_{i t}$ summarize a politician's congressional experience, where $T H_{i t}$ and $T S_{i t}$ are the number of prior terms served in the House and Senate, respectively, and $C O M_{i t}$ is a dummy for whether, during the prior House term, a representative served on a major committee. ${ }^{7}$ Moreover, if politician $i$ is no longer in Congress in period $t, V E_{i t}$ is an indicator for whether he/she left Congress voluntarily or by losing a reelection bid.

The variables Skill $_{i}$ and Achieve $_{i}$ denote a politician's unobserved type. Skill ${ }_{i}$ is a dummy equal to 1 if the politician is "skilled" (i.e., he/she possesses characteristics, such as "valence" or "charisma," that increase the probability of winning elections), while Achieve $_{i}$ indicates the preference-type of a politician; it equals 1 if the politician values legislative achievements (i.e., what we call an achiever). Crossing $S k i l l_{i}$ with Achieve $_{i}$ gives four possible types of politicians.

\footnotetext{
${ }^{7}$ Following Deering and Smith (1990), the major committees are Ways and Means, Appropriations, and Rules.
} 
We emphasize that we do not observe latent types directly. Rather, a politician's likely type is inferred in the estimation of the structural model. Loosely speaking, a politician is likely to be skilled if he/she wins many elections, particularly under difficult circumstances (see below), and is likely to be an achiever if he/she has a relatively large number of legislative accomplishments.

The variables $S O D_{i}$ ("state-of-the-district"), $S O S_{i t}$ ("state-of-the-State"), and $S O W_{t}$ ("stateof-the-world"), measure the political climate surrounding elections. They indicate, respectively, whether local district conditions (if the politician is a member of the House), State-wide conditions and National conditions favor election of a Democrat or a Republican or are neutral. The variable Scandal $i_{i t}$ is an indicator for being involved in a scandal at time $t$, and, if a politician is a member of the House, Redist ${ }_{i t}$ is an indicator for whether his/her district has been affected by redistricting during the current period. The construction of these variables is described in detail in DKM.

The variables $E S_{i t}, C_{y c l e}$, and $I N C_{i t}$ summarize the status of the two Senate seats in a representative's State, which affects his/her chances to run for higher office. As a Senate term is six years and State senatorial elections are staggered, the variables $C y c l e_{i t}$ and $I N C_{i t}$ characterize the current position of a representative's State in its "Senate cycle," and the incumbency status of the two Senate seats, respectively. ${ }^{8}$ The variable $E S_{i t}$ ("election status") describes the set of options available to representative $i$ at time $t$ : Either no Senate seat is up for election in the representative's State (in which case his/her only options are to run for reelection or leave Congress), or a Senate seat is up for election and there is either an incumbent Democratic or Republican senator running for reelection, or the seat is open (i.e., no incumbent is running for reelection).

The variable $S T_{i t}$ ("Senate term") characterizes the options available to senator $i$ at time $t$. It equals 2,4 or 6 . If a senator has served 2 or 4 years of his/her term, the options are to continue to serve or exit Congress. If $S T=6$ the term is up and the senator must decide whether to run for reelection or exit Congress. Finally, to capture important institutional changes over time, Cohort $_{i}$ is a variable indicating whether a politician entered Congress in 1947-1965, 1967-1975 or 1977-1993.

\subsection{Decisions of Politicians upon Leaving Congress}

Politicians in our model solve a finite-horizon discrete dynamic programming (DP) problem in order to determine their optimal choice in each period. Such problems are generally solved "backwards." Thus, we first describe the choice problem faced by a member of Congress at the end

\footnotetext{
${ }^{8}$ There are three possible positions in the Senate cycle, depending on whether a seat is currently up for election and the other seat is coming up for election in either one or two periods, or neither seat is currently up for election. There are four possible incumbency configurations depending on the party affiliations of the two sitting senators.
} 
of his/her congressional career - i.e., when he/she exits Congress (either voluntarily or via electoral defeat). At that point, the politician can choose between three options: work in a private sector occupation, work in the public sector (i.e., another political job) or retirement. The wages a politician may obtain in the two occupations are given by: ${ }^{9}$

$$
W_{i j t}=W_{j}\left(X P_{i t}\right)+\varepsilon_{i j t},
$$

where $j=1,2$ denote employment in the private and public sector, respectively, and $W_{j}\left(X P_{i t}\right)$ is the deterministic part of the wage offered to individual $i$ in occupation $j$ in period $t$. This depends on $X P_{i t}$ the politician's state at the time he/she exits Congress, which, the reader will recall, includes congressional experience, which enhances post-congressional wage offers. It also includes age, education, political skill, ${ }^{10}$ and whether he/she left Congress voluntarily or via electoral defeat. The term $\varepsilon_{i j t}$ represents the purely stochastic component of the wage offer, which is revealed when the politician exits Congress. Then, the payoffs to an individual in the two working options are:

$$
\begin{array}{ll}
P W_{i 1 t}=W_{i 1 t}+\alpha_{1 C} C O M_{i t}, & \text { (private sector) } \\
P W_{i 2 t}=W_{i 2 t}+\alpha_{2 C} C O M_{i t}+\alpha_{2 W}, & \text { (public sector), }
\end{array}
$$

where the terms $\alpha_{1 C}$ and $\alpha_{2 C}$ are the monetized value of having served on a major House committee (which may generate additional income from speaking engagements, consulting, book contracts, etc., and which may differ between the private and public sector), and $\alpha_{2 W}$ captures the monetized value of the non-pecuniary rewards from holding a political job. ${ }^{11}$

If, on the other hand, a politician retires after exiting Congress, he/she may, depending on age and length of service, be eligible to receive pension payments according to the congressional pension rule $P E_{i t}\left(A g e_{i t}, T H_{i t}, T S_{i t}\right)$. Then, the payoff in the retirement option is:

$$
P R_{i t}=P E_{i t}\left(A g e_{i t}, T H_{i t}, T S_{i t}\right)+\alpha_{L}+\alpha_{V E} V E_{i t},
$$

where the term $\alpha_{L}$ captures the monetized value of leisure. $V E_{i t}$ is a dummy indicating that a politician left Congress voluntarily (rather than via electoral defeat), and $\alpha_{V E}$ captures an additional

\footnotetext{
${ }^{9}$ By other political jobs we are thinking primarily of appointed positions, such as cabinet posts, bureaucratic positions, etc. We abstract from the fact that a politician might have to run or be confirmed for some such positions.

${ }^{10}$ That is, we allow for the possibility that political skill also enhances productivity in the private sector. However, the estimates of the model imply that the two are not significantly correlated.

${ }^{11}$ Note that DKM allowed unobserved (i.e., non-wage) payoffs in post-congressional careers to differ depending on committee status, but not on other elements of $X P$. This is only because they had a particular interest in testing for evidence that serving on major committees led to extra non-wage rewards after Congress (e.g., consulting). In the event,
} 
value of leisure for such politicians. We include this term because politicians who voluntarily exit are far more likely to completely retire after leaving Congress (rather than taking another job). Thus, we take voluntary exit as an indicator that the politician may be ready for retirement.

Together, (5), (6) and (7) give the per-period payoffs for each of the three post-congressional alternatives a politician faces at exit. ${ }^{12}$ But, of course, a politician's choice after leaving Congress depends on the expected present value of the whole stream of future payoffs (until the end of life) associated with each option. Let $P V_{j}\left(X P_{i t}, \varepsilon_{i j t}\right)$ for $j=1,2$ and $P V_{3}\left(X P_{i t}\right)$ denote these present values for the private sector, public sector and retirement option, respectively. The calculation of these present values depends on death and retirement transition probabilities, as well as congressional pension rules, in a fairly complex way, so we refer the reader to DKM for details.

Throughout the model, we assume there is a mean-zero, idiosyncratic (politician specific) taste shock associated with each possible choice in each decision period. Such an assumption is standard in discrete choice modeling, as the existence of such unobservables (i.e., aspects of payoffs that agents observe but we don't) is not only reasonable, but also necessary. Otherwise, we could not explain why agents with identical observed state variables often make different choices. For post-congressional choices, let $\left(\xi_{i 1 t}, \xi_{i 2 t}, \xi_{i 3 t}\right)$ denote the vector of taste shocks (or unobserved nonpecuniary rewards) for politician $i$ at time $t$ associated with private and public sectors employment and retirement, respectively. Then the expected value of the decision to exit Congress is given by:

$$
V_{E}\left(X P_{i t}\right)=E_{\varepsilon} E_{\xi} \max \left\{P V_{1}\left(X P_{i t}, \varepsilon_{i 1 t}\right)+\xi_{i 1 t}, P V_{2}\left(X P_{i t}, \varepsilon_{i 2 t}\right)+\xi_{i 2 t}, P V_{3}\left(X P_{i t}\right)+\xi_{i 3 t}\right\}
$$

This equation says the value of exit in state $X P_{i t}$ is the maximum of the payoffs from the three options (private job, public job, retire). But, at the time a politician is deciding whether to exit Congress, he/she can only form an expectation of this object; the politician does not yet know what the stochastic part of wage offers $\left\{\varepsilon_{i j t}\right\}_{j=1,2}$ will be, ${ }^{13}$ or what the alternative specific taste shocks

\footnotetext{
they found no evidence of such an effect (i.e., $\alpha_{I C}$ and $\alpha_{2 C}$ were small and insignificant). In contrast, they found that $\alpha_{2 W}$, the monetized value of the non-pecuniary rewards from holding a political job, was quite large and highly significant.

${ }^{12}$ It is worth noting that the payoff functions (5)-(7) embody a set of exclusion restrictions. These can be seen more clearly by also examining (1)-(3). Note that some variables are assumed to affect decisions and outcomes for sitting members of Congress (e.g., Party, Scandal, measures of the electoral climate) but not to affect post-congressional payoffs. Conversely, the variable $V E$ (voluntary exit), as well as the pension rules, only affect post-congressional payoffs. DKM provide a detailed discussion of these exclusions (see their Section I.D). As an example, they argue it is natural to assume the electoral climate influences election probabilities, but that it does not affect post-congressional wages (although one could obviously tell stories where it does). Some exclusion restrictions were made more pragmatically: For instance, it would be plausible to expect variables like Party or Scandal to affect post-congressional wages, but in preliminary analysis of the wage data DKM found no evidence of such effects.

${ }^{13}$ This can be interpreted as assuming that firms cannot make job offers to politicians while they are still in Congress.
} 
$\left\{\xi_{i j t}\right\}_{j=1,3}$ will be. The notation $E_{\varepsilon} E_{\xi}$ denotes the expectation taken over possible values of these draws. Of course, upon exiting Congress the wage and taste shocks are revealed to the politician, who is aware of them at the time he/she chooses a post-congressional occupation or retirement. ${ }^{14}$

We refer the reader to DKM for details of how to numerically calculate the expression in (8). For our purposes, the most crucial point is that it is increasing in congressional experience including terms in the House and Senate and important committee membership - as such experience generates returns in the post-congressional options (including both the employment option, where it raises wages and non-pecuniary rewards, and the retirement option, where it raises pensions).

\subsection{Decisions of Sitting Senators}

Next we describe decisions of senators. If the senator's seat is not up for election, the choice is simply to stay in office or exit. If the senator decides to stay in office, he/she receives the perperiod payoff from sitting in the Senate, which includes both the wage and non-pecuniary rewards. Denote by $V_{S}\left(X S_{i t}, s\right)$ the value of remaining in the Senate given the relevant state variables $\left(X S_{i t}, s\right)$, where the second element of the state vector indicates the politician is a sitting senator. We have:

$$
V_{S}\left(X S_{i t}, s\right)=W_{S}(t)+\alpha_{S}+\text { Achieve }_{i} p_{A S}\left(X S_{i t}\right) \alpha_{A S}+\mu_{1 S i t}+\delta\left(1-\pi_{d}\left(\text { Age }_{i t}\right)\right) E V\left(X S_{i, t+1}, s\right) .
$$

The first four terms in (9) capture current payoffs from sitting in the Senate at time $t . W_{S}(t)$ is the Senate wage, and $\alpha_{S}$ is the monetized value of non-pecuniary rewards (i.e., perks or prestige). In addition, the achiever types - i.e., those who value legislative achievements $\left(\right.$ Achieve $\left._{i}=1\right)$ - get an added payoff contingent on realizing such an achievement. We let $\alpha_{A S}$ denote the monetized value of the reward an achievement generates, while $p_{A S}\left(X S_{i t}\right)$ denotes the probability of having an achievement. ${ }^{15}$ This depends on the senator's type and congressional experience. The term $\mu_{I S i t}$ is a mean-zero stochastic shock to $i$ 's utility from being in the Senate at time $t$. This captures random fluctuations in tastes and/or non-pecuniary rewards over time.

The last term in (9), $E V\left(X S_{i, t+1}, s\right)$, is the expected present value of the politician's state in period $t+1$, given that he/she chooses to remain in the Senate until that point. This is multiplied by

\footnotetext{
${ }^{14}$ While the taste shocks enable the model to explain why politicians who are ex-ante identical make different choices, the wage shocks enable the model to explain why politicians who are ex-ante identical have different wage realizations. Note that the presence of the wage shocks does not enable one to dispense with the taste shocks - so long as wages are actually observed. For instance, it would then be impossible for the model to explain why politicians are in some instances observed to accept low wage jobs rather than opting for complete retirement.

${ }^{15}$ Following Mayhew (2000), we define important legislative achievements to include, e.g., sponsoring a major piece of legislature or casting the decisive vote on an important policy issue. It is only because we have data on achievements by individual members of Congress that we can estimate the fraction of members who are achievers. We can also assign to each member of Congress the ex post probability that he/she is an achiever, based on his/her legislative history.
} 
the discount factor $\delta$ and the survival probability $\left(1-\pi_{d}\left(A g e_{i t}\right)\right)$, as one must survive to receive the future payoff. It is perhaps easiest to understand what $E V\left(X S_{i, t+1}, s\right)$ is by considering a case where term limits have been imposed, so the senator must exit at $t+1$. Then, $E V\left(X S_{i, t+1}, s\right)$ is simply the expected value of exiting Congress, $V_{E}\left(X P_{i t}\right)$, given in (8). More generally, $E V\left(X S_{i, t+1}, s\right)$ is the expected maximum of the value of exit and the value of staying in the Senate in period $t+1$ :

$$
E V\left(X S_{i, t+1}, s\right)=E \max \left\{V_{S}\left(X S_{i, t+1}, s\right), V_{E}\left(X P_{i, t+1}\right)\right\}
$$

Now consider the case where a senator's seat is up for election at $t+1$. Then $E V\left(X S_{i, t+1}, s\right)$ is equal to the expected maximum of the value of exit and the value of running for re-election - which we denote $V_{R S}\left(X S_{i, t+1}, s\right)$ and discuss further below. Specifically, we have:

$$
E V\left(X S_{i, t+1}, s\right)=E \max \left\{V_{R S}\left(X S_{i, t+1}, s\right), V_{E}\left(X P_{i, t+1}\right)\right\},
$$

We now define $V_{R S}\left(X S_{i, t+1}, s\right)$. Consider a senator whose seat is currently up for election, so the choice is either to run for re-election or leave Congress. If the senator runs, the probability of winning, $p_{s}\left(X S_{i t}\right)$, depends on skill, age, experience, party, whether there is any scandal, and the political climate. As a senator who loses a re-election bid must exit Congress and make a postcongressional career decision, the value of running for reelection to the Senate is given by:

$$
V_{R S}\left(X S_{i t}, s\right)=p_{S}\left(X S_{i t}\right) E V_{S}\left(X S_{i t}, s\right)+\left(1-p_{S}\left(X S_{i t}\right)\right) V_{E}\left(X P_{i t}^{*}\right)+\alpha_{R S}+\mu_{R S i t} .
$$

Here, $\alpha_{R S}$ is the monetized value of the utility from running for the Senate (net of costs of running), and $\mu_{R S i t}$ is the idiosyncratic shock to senator $i$ 's utility from running for reelection at time $t .{ }^{16}$

Now, combining the above expressions, we have that a senator whose seat is not up for reelection will choose to stay in the Senate if and only if equation (9) exceeds equation (8) - i.e., if $V_{S}\left(X S_{i t}, s\right)>V_{E}\left(X P_{i t}\right)$ - while a senator whose seat is up for re-election will choose to run if and only if equation (11) exceeds equation (8) - i.e., if $V_{R S}\left(X S_{i t}, s\right)>V_{E}\left(X P_{i t}\right)$.

\subsection{Decisions of Members of the House of Representatives}

We next consider the decisions of House members. The timing of events is as follows: At the end of a two-year term, the representative decides whether to exit, run for reelection, or, if the option is available, run for the Senate. At the time of this decision, he/she knows the political climate for the upcoming elections, whether his/her district was affected by redistricting, and if he/she is involved in any scandal. Along with political skills, party affiliation, and congressional

\footnotetext{
${ }^{16}$ In (11), $X P_{i t}{ }^{*}$ denotes the sub-vector of $X P_{i t}$ with $V E_{i t}$ set to 0 , as the senator exits via losing rather than voluntarily.
} 
experience, all these variables affect electoral prospects. The representative also knows whether a Senate seat is up for election, whether an incumbent will run for the seat, and, if so, the party of the incumbent, all of which affect his/her chances of success in a bid for higher office. ${ }^{17}$

Consider a representative's decision when running for the Senate, running for reelection, or exiting Congress are all available options. The value of running for the Senate is then:

$$
V_{R S}\left(X H_{i t}, h\right)=p_{H S}\left(X H_{i t}\right) E V_{S}\left(X S_{S}, s\right)+\left(1-p_{H S}\left(X H_{i t}\right)\right) V_{E}\left(X P_{i t}^{*}\right)+\alpha_{H S}+\mu_{H S i t},
$$

where $h$ indicates the politician is sitting in the House. Equation (12) resembles (11), the value to a sitting senator of running for Senate, except that, for a representative, both the probability of winning, $p_{H S}\left(X H_{i t}\right)$, and the utility/disutility of running for Senate, $\alpha_{H S}$, are different.

On the other hand, the value of running for reelection to the House is:

$$
V_{R H}\left(X H_{i t}, h\right)=p_{H}\left(X H_{i t}\right) E V_{H}\left(X H_{i t}, h\right)+\left(1-p_{H}\left(X H_{i t}\right)\right) V_{E}\left(X P_{i t}^{*}\right)+\alpha_{R H}+\mu_{R H i t},
$$

where $p_{H}\left(X H_{i t}\right)$ is the probability of winning reelection, $\alpha_{R H}$ is the monetized value of the utility a representative gets from running for the House (net of the cost of running), and $\mu_{R H i t}$ is a mean-zero idiosyncratic shock to representative $i$ 's utility from running for reelection at time $t$.

The expected value of sitting in the House given reelection at time $t$ is:

$$
E V_{H}\left(X H_{i t}, h\right)=W_{H}(t)+\alpha_{H}+p_{C}\left(X H_{i t}^{*}\right) \alpha_{C}+\text { Achieve }_{i} p_{A H}\left(X H_{i t}\right) \alpha_{A H}+\delta\left(1-\pi_{d}\left(A g e_{i t}\right)\right) E V\left(X H_{i, t+1}, h\right)
$$

The first four terms in (14) capture current payoffs from sitting in the House at time $t . W_{H}(t)$ is the House wage, and $\alpha_{H}$ is the monetized value of per-period non-pecuniary rewards from being in the House. The term $\alpha_{C}$ is the monetized value of the non-pecuniary benefit of being named to a major committee, and $p_{C}\left(X H_{i t}{ }^{*}\right)$ is the probability of being named. ${ }^{18}$ In addition, if a representative is the achiever type (i.e., Achieve $_{i}=1$ ) he/she may receive additional utility $\left(\alpha_{A H}\right)$ contingent on having an important legislative accomplishment, which occurs with probability $p_{A H}\left(X H_{i t}\right)$.

The last term in (14) is the "future component" of the value of staying in the House, which consists of the expected present value of payoffs from $t+1$ onward. If a Senate seat is up for election in the representative's State at $t+1$, this is equal to the expected maximum of the values of exit, running for Senate, and running for reelection to the House in period $t+1$ :

\footnotetext{
${ }^{17}$ For example, if there is an incumbent senator of the representative's own party running for the seat, there is little chance of success. If the incumbent is from the other party then the chances of winning may be better, but they are still small. If the seat is open, however, the representative's chances of winning may improve substantially.

${ }^{18}$ Recall that in (1) we defined $X H_{i t}$ as including the House committee status state variable $C O M_{i t}$. Hence, we let $X H_{i t}{ }^{*}$ denote the vector of state variables $X H_{i t}$, but with $C O M_{i t}$ replaced by $C O M_{i, t-1}$.
} 


$$
E V\left(X H_{i, t+1}, h\right)=E \max \left\{V_{R S}\left(X H_{i, t+1}, h\right), V_{R H}\left(X H_{i, t+1}, h\right), V_{E}\left(X P_{i, t+1}\right)\right\}
$$

But if no Senate seat will be up for election in the representative's State at $t+1$, it is simply the expected maximum of the value of exit and the value of running for reelection in period $t+1$ :

$$
E V\left(X H_{i, t+1}, h\right)=E \max \left\{V_{R H}\left(X H_{i, t+1}, h\right), V_{E}\left(X P_{i, t+1}\right)\right\},
$$

In each case, the expectation is taken over information that will be revealed between $t$ and $t+1$.

Solution of the model generates probability distributions of the career decisions of members of Congress, conditional on their state variables. We can also calculate the "value" of a seat in Congress, which is the monetary payment that renders a member of Congress indifferent between giving up his/her seat and continuing his/her congressional career. This is the difference between the value function for remaining in Congress and that for voluntarily exiting Congress.

\subsection{Type Probabilities and Probabilities of Winning Elections and of Committee Assignment}

As noted above, we allow for two types of unobserved heterogeneity among politicians (i.e., whether they are skilled and whether they are achievers). To help predict the unobservable type of a politician, DKM specify two type-probability functions, $\pi_{S}$ and $\pi_{A}$, which depend on observable background characteristics of the politician - namely, whether he/she held another elected office prior to entering Congress, whether he/she comes from a political family, ${ }^{19}$ the politician's age when first entering Congress, whether the politician entered Congress as a representative or a senator, whether he/she serves in the same State where he/she was born, and his/her party affiliation. ${ }^{20}$

DKM estimate that age at entry, prior political experience and coming from a political family are positively correlated with being the skilled type. But the latter two associations are imprecisely estimated. Being an achiever is negatively associated with age at entry and prior political experience, but positively associated with coming from a political family and entering the Senate directly. Being an achiever type and a skilled type are mildly negatively correlated. ${ }^{21}$

Conditional on being an achiever type, the politician has a probability of actually realizing an important legislative achievement during any given time period. Earlier we denoted these by $p_{A S}\left(X S_{i t}\right)$ and $p_{A H}\left(X H_{i t}\right)$, as they differ between the House and Senate. DKM estimate that the only significant predictors of achievement in the House are seniority and being a member of the majority (Democratic) party, while the only significant predictor of achievement in the Senate is seniority.

\footnotetext{
${ }^{19}$ In particular, a politician comes from a political family if he/she has relatives who had already been elected to Congress. See also Dal Bo, Dal Bo and Snyder (2008).

${ }^{20}$ The probability functions described in this section are all specified as logit functions of the relevant state variables.
} 
Finally, the model contains four functions that determine the probabilities of winning elections, $p_{S}\left(X S_{i t}\right), p_{H}\left(X H_{i t}\right)$, and $p_{H S}\left(X H_{i t}\right)$, and of being named to a major committee, $p_{C}\left(X H_{i t}{ }^{*}\right)$. DKM estimate that significant determinants of the probability of winning re-election to the House, besides of course the political climate and political skill, are seniority, key committee membership and age, which have positive effects, and redistricting and scandal, which have negative effects. Conditional on re-election, the probability of being named to a major committee is significantly positively associated with seniority and age. The significant determinants of probability of winning re-election to the Senate, besides the political climate and political skill, are only age, which has a positive effect, and scandal, which has a negative effect. In addition, if seeking election to the Senate from the House, the probability of success depends positively on seniority in the House.

\subsection{Data and Estimation of the Model}

By specifying functional forms for the probability and wage functions as well as the distributions of the wage and taste shocks, DKM estimate the model described above by maximum likelihood using a newly collected data set containing detailed information on the careers of all House and Senate members who entered Congress from 1947 (the $80^{\text {th }}$ Congress) to 1993 (the $103^{\text {rd }}$ Congress), and either exited prior to or were still in Congress as of January 1995 (the inauguration of the $104^{\text {th }}$ Congress). For each individual in the sample, the data set contains: (a) biographical data (i.e., age, place of birth, education, family background, party affiliation, prior political experience) and the record of congressional service; (b) a record of committee membership, any scandals while serving in Congress and congressional wages; (c) redistricting and congressional opportunities data (i.e., opportunities to run for a Senate seat); (d) a record of important legislative accomplishments (i.e., sponsoring major pieces of legislation, delivering famous speeches, casting decisive votes on important issues); (e) post-congressional data (i.e., type of first job after service, first annual salary, pension benefits). DKM show that the estimated model tracks the observed behavior of politicians throughout their congressional careers remarkably well. ${ }^{22}$ This gives us some confidence in using the estimated model to conduct a series of policy experiments, which we present in Section 3.

But before we proceed, some discussion is in order regarding the precision of the estimates and how this influences the reliability of the policy experiments. We refer the reader to DKM Table 2 for details of the estimates, but some key points are worth noting. First, the functions that describe

\footnotetext{
${ }^{21}$ The probability of being an achiever conditional on being skilled is $24 \%$. That conditional on being unskilled is $30 \%$.

${ }^{22}$ See Diermeier, Keane and Merlo $(2004,2005)$ for a more detailed description of the data, the exact parameterization of the model, and details on the solution and estimation of the model.
} 
probabilities of winning, being named to major committees, or having political achievements, are all quite precisely estimated. Post-congressional wage functions and non-monetary rewards from postcongressional career choices are precisely estimated as well. In contrast, some of the parameters that describe utilities from sitting in Congress or running for election are imprecisely estimated. This occurs because these two sources of non-monetary rewards are hard to disentangle:

Intuitively, one could rebalance the source of these rewards (e.g., increase the reward to sitting and reduce the reward from running) while leaving the expected present value of the nonmonetary rewards to a member of Congress roughly unchanged, and hence their behavior roughly unchanged. This sort of parameter uncertainty would be of great concern if any of our experiments involved changing the composition of non-pecuniary rewards to members of Congress.

For this reason, we only consider experiments that involve changing either monetary rewards, probabilities of election or probabilities of being named to committees. Thus, all of our experiments involve shifting parameters of functions that are precisely estimated. The model should give rather precise predictions of the effects of changing such parameters.

A key part of our analysis is to examine how our policy experiments affect different types of politicians. Inspection of the DKM estimates in their Table 2 reveals that effects of being a skilled type (on election probabilities, committee probabilities, and post-congressional wages) are precisely estimated. The probability-of-achievement functions are also precisely estimated, as are the effects of political party (on election probabilities and probability of achievements). Therefore we expect to obtain reasonably precise predictions of how experiments differentially affect skilled politicians, achievers and members of different parties. Also, DKM let background variables (age at entry to Congress, prior political experience, having a "political" family) affect probabilities of being the skilled or achiever type. But effects of these variables on type probabilities are not precisely estimated, with the exception of age at entry. Thus, we look at how policies differentially affect politicians who differ in age at entry to Congress, but ignore other background variables.

\section{Policy Experiments}

\subsection{Overview}

In this section, we use the DKM framework to perform a variety of policy experiments aimed at assessing the extent to which the career choices of politicians respond to changes in monetary incentives and/or career opportunities. We consider three sets of policies. The first set limits the career prospects of politicians, either within Congress or in their post-congressional 
employment opportunities. The second set of policies alters the monetary rewards to holding a seat in Congress. The third and final set of policies limits opportunities for re-election.

To conduct our experiments, we simulate, using the estimated model, the career histories of 10,000 politicians with the same distribution of initial conditions (i.e., age, education, family background, type, party affiliation, prior political experience and whether they enter Congress in the House or the Senate) as in the data. We conduct the simulations both under a "baseline" scenario, which corresponds to the actual environment, as well as under the alternative scenarios defined by each of the counterfactual policy experiments we consider.

The results of the experiments are reported in Tables 1 through 5. Table 1 reports how each policy change affects the average duration of congressional careers. Table 2 reports how each experiment affects choices of representatives (i.e., the probability they run for re-election, run for higher office or leave Congress). Similarly, Table 3 reports how the experiments affect choices of senators. Table 4 describes how each experiment alters the value of a House or Senate seat, defined as the monetary payment that would make a member of Congress indifferent between staying in Congress and exiting. ${ }^{23}$ Finally, Table 5 reports how the experiments alter decisions of politicians when they exit Congress (the percent who take private or public sector jobs, or retire completely).

The most important aspect of Tables 1-5 is that we report not just how each experiment affects the average behavior of politicians, but also how it affects the behavior of particular types of politicians. The characteristics of politicians that we consider are his/her latent type (i.e., whether he/she is a skilled type or an achiever type), political party, and age at time of entry into Congress.

The reason we look at these characteristics is that it is of considerable interest to ask whether the policies we consider might alter the composition of Congress along these dimensions. For example, one might be particularly concerned about a policy that lowers the value of a seat in Congress for the type that values legislative achievement relative to the type that does not.

Before we present our results, two important caveats are in order. First, as the data used in estimation only contain members of Congress, our analysis is conditional on election to Congress. Thus, we can only evaluate the impact of policy changes on career decisions of politicians who are already members of Congress, not on the composition of the pool of potential candidates.

\footnotetext{
${ }^{23}$ For example, a senator whose seat is up for re-election would choose to run if and only if equation (11) exceeds equation (8), that is if $V_{R S}\left(X S_{i t} s\right)>V_{E}\left(X P_{i t}\right)$. To calculate the value of the seat to such a senator, we must calculate the amount by which $V_{R S}\left(X S_{i t} s\right)$ exceeds $V_{E}\left(X P_{i t}\right)$. A payment of this magnitude would render the politician indifferent between running for re-election and exiting voluntarily. Viewed another way, the "value of the seat" is how much better off the politician is by remaining in Congress rather than exiting, converted into monetary terms.
} 
Nevertheless, we believe our analysis is still suggestive in this regard. For instance, policies that lower the value of a congressional seat for achievers relative to non-achievers would typically reduce the relative number of achievers who run for Congress in the first place. But we cannot go beyond this qualitative statement to make any quantitative assessment of the impact on the pool of candidates. A second (and related) point is that our experiments assume all model parameters are policy invariant, yet one could imagine that some policies alter some model parameters. For example, policies that alter probabilities of being named to major committees, or of being reelected, may, in equilibrium, alter the values of committee membership or congressional experience in post-congressional careers. Such considerations are beyond the scope of our analysis.

\subsection{Baseline Simulation}

Before turning to the experiments, a few aspects of the baseline simulation are notable. First, as we see in Table 1, while the average duration of a political career is 9.61 years, it is much greater for skilled politicians than others (12.72 vs. 7.51 years), and it is greater for achievers than for nonachievers (10.56 vs. 9.29 years). As we see in Table 2, achiever representatives have a much higher probability of running for Senate than non-achievers ( $4.03 \%$ vs. $2.75 \%)$, yet they also have a higher probability of running for re-election $(92.27 \%$ vs. $90.90 \%)$. Skilled representatives have a slightly lower probability of running for re-election than unskilled, but a much higher probability of running for Senate $(4.37 \%$ vs. $1.29 \%)$.

In Table 4 , the average value of a House seat is $\$ 616,228$. But this value is quite a bit greater for achievers than non-achievers $(\$ 683,641$ vs. $\$ 594,434)$, and for the skilled than the unskilled $(\$ 658,294$ vs. $\$ 559,425)$. The larger value for achievers arises since they get utility from legislative accomplishments, a non-monetary return to office that other politicians do not get. And the value is greater for skilled politicians primarily because they are more likely to win re-election attempts.

Finally, in Table 5, we see that skilled politicians are much more likely to completely retire when they leave Congress than unskilled (27.2\% vs. $7.6 \%)$. This is because skilled politicians rarely exit via electoral defeat, but rather because they have actually chosen to retire. Interestingly, conditional on continuing to work, skilled politicians are more likely to choose private sector employment than unskilled politicians (61\% vs. $56 \%$ ).

\subsection{Policies that Limit Career Advancement Inside and Outside Congress}

As DKM emphasize, the value of a House seat arises both from the opportunity for career advancement within Congress (i.e., being named to an important House committee or successfully 
moving from the lower to the upper house of Congress), and from the value of congressional experience in post-congressional careers. In the first group of experiments we consider policies that limit such possibilities for career advancement (either in or out of Congress).

Experiment 1a (NOCOMSENIOR): According to DKM's estimates, the probability of being named to a major House committee is increasing in seniority. Being named to a committee also increases the probability of re-election, and has a modest positive effect on the non-pecuniary rewards from sitting in the House. The increase in committee probability with seniority should increase the option value of running for re-election. However, it is not at all clear from the point estimates if this effect is quantitatively large, or for which types of politicians it would be largest.

Thus, our first policy experiment is a change in rules to eliminate any seniority advantage for being named to important House committees. The effect of this policy can be seen by comparing the second column of Tables 1 through 5, which describe behavior under the policy, with the first column, which describes behavior under the baseline. For instance, in Table 1, we see that the policy reduces average length of service in the House from 4.49 to 4.44 terms - a very minor effect.

It is notable, however, that the average length of service for achievers actually increases from 4.71 to 4.80 terms, while that of non-achievers drops from 4.42 to 4.34 terms. The reason this occurs is that, without seniority as a determinant of committee appointment, achievers are more likely to be named to major committees. ${ }^{24}$ This gives achievers an incentive to stay in the House longer. ${ }^{25}$ Hence such a policy would appear to have desirable features in terms of its influence on the composition of the House (though the effect is modest).

In another experiment which we do not report in detail (see the working paper Keane and Merlo (2007)) we considered eliminating House committees altogether. This is obviously highly unrealistic, but it is useful for assessing the role that chances of being named to an important committee play in politicians' career decisions. Not surprisingly, it has much larger effects -i.e., a reduction in the average number of House terms from 4.49 to 4.27 . The value of a House seat is

\footnotetext{
${ }^{24}$ Recall from Section 2.5 that achievers are less likely to be the skilled type, making it harder for them to gain seniority via repeated re-election.

${ }^{25}$ There are two apparently puzzling aspects of this result. First, for achievers, the average length of service increases even though the probability of running for re-election drops from $92.27 \%$ to $92.03 \%$. This can be explained by the fact that probability of winning re-election is higher for members of important committees, and the policy change makes them more likely to be named to such committees. Second, the value of a House seat for the achiever type goes down, from $\$ 683 \mathrm{k}$ to $\$ 674 \mathrm{k}$, which may appear inconsistent with longer average length of service. However, recall that the value of a House seat is the difference $\max \left\{V_{R H}\left(X H_{i t}, h\right), V_{R S}\left(X H_{i t}, h\right)\right\}-\mathrm{V}_{\mathrm{E}}\left(\mathrm{XP}_{\mathrm{it}}\right)$. As committee membership is valuable in post-congressional employment, making committee membership more likely for achievers will raise their value of the outside option, accounting for both the lower value of a seat and the lower probability of seeking re-election.
} 
reduced from $\$ 616,228$ to $\$ 600,989$, or $2.5 \%$. Thus, it appears the possibility of major committee membership plays a modest but non-negligible role in generating the value of a House seat.

Another type of career advancement for House members is to succeed in being elected to the Senate. In another experiment not reported (see Keane and Merlo (2007) for details) we eliminate the option of House members to run for Senate. This reduces the value of a House seat from $\$ 616,228$ to $\$ 601,187$, or $2.4 \%$. Thus, the option of running for Senate and the chance of being named to a major committee play similar modest roles in generating the value of a House seat.

Experiment $1 \boldsymbol{b}$ (NOPRIV): The DKM estimates imply that congressional experience is valued in both the private and public sectors. Thus, another form of career advancement is to exit Congress to take up post-congressional employment where congressional experience is valuable. Here, we consider an experiment where we preclude members of Congress from accepting private sector employment. This is actually of some policy relevance. While a private sector employment ban is certainly not a serious proposal, curtailing it in various ways, such as precluding lobbying activities or employment with firms that rely on government contracts, are policies that have been seriously discussed. This experiment can give us an idea of the direction of impact of such policies.

On average, this policy increases duration of congressional careers from 9.61 to 9.94 years, increases the probability a House member seeks re-election from $91.23 \%$ to $92.45 \%$, sharply reduces the probability a House member runs for Senate from $3.07 \%$ to $1.76 \%$, and increases the value of a House seat from $\$ 616,228$ to $\$ 663,271$ (or $7.6 \%$ ). It may seem puzzling that a policy that renders congressional experience worthless in the private sector would increase the value of a seat in Congress. However, recall that the value of a seat is the difference in the expected present value of lifetime payoffs if the politician seeks re-election to his/her seat vs. choosing to exit Congress. Thus, this policy increases the value of a seat by reducing the politician's earnings capacity outside of Congress. In response, politicians make a greater effort to stay in Congress. One manifestation of this is that House members avoid running for Senate, which is generally a very risky venture.

The effects of this policy differ radically by type. For skilled politicians the average career duration increases from 12.72 to 13.81 years, while for the unskilled it declines slightly, from 7.51 to 7.45. Similarly, the probability a skilled politician runs for re-election increases from $91.05 \%$ to 93.28\%, while for unskilled politicians it falls slightly (from $91.48 \%$ to $91.21 \%$ ). And the value of a House seat increases by $\$ 73,000$ for the former and only $\$ 3,000$ for latter. Here the dynamics of the model come into play. The skilled politician has a very high probability of winning elections. Thus, 
with post-congressional opportunities curtailed, it is optimal to try harder to hold on to his/her valuable seat. The same is true of unskilled politicians. But for them there is a countervailing force. They know their probability of winning elections is not so high, and there is a good chance they will eventually be pushed unwillingly into the post-congressional labor market, where their experience is now worth much less. In a sense they are better off if this were to happen sooner rather than later. These two forces roughly cancel, leaving the value of a seat essentially unchanged.

Another interesting aspect of this policy is that it has a much larger effect on achievers than non-achievers. For achievers the average duration of a political career increases by 0.49 years (from 10.56 to 11.05 years), while for non-achievers it increases by only 0.27 years (from 9.29 to 9.56). Thus, this policy would appear to be "beneficial" in the sense of shifting the composition of Congress towards the achiever type.

It is notable that these differences in policy effects by type would have been difficult if not impossible to predict based only on point estimates for effects of experience on post-congressional wages. These parameters are not type specific, so the differences by type arise only because of the overall structure of the model. Indeed, none of the model parameters are type specific.

It is also worth noting the effects of restricting private sector employment on postcongressional career choices. Not surprisingly, eliminating the option of entering the private sector increases the fraction of politicians who completely retire upon exiting Congress from $15.5 \%$ to $29 \%$, while increasing the fraction who choose to work in the public sector from $36 \%$ to $71 \%$. There is a substantial difference in behavior between skilled and unskilled politicians. For the skilled, the fraction who completely retire increases from $27 \%$ to $47 \%$. For the unskilled, it increases is from $7.6 \%$ to $17 \%$. The skilled are much more likely to completely retire in either case, because when they leave Congress it is more likely to be via voluntary retirement than via electoral defeat. ${ }^{26}$

Finally, in another experiment described in detail in Keane and Merlo (2007), we preclude former members of Congress from taking other positions in the public sector. This is an experiment of no policy relevance, but it addresses the question: "To what extent does the value of a seat in the

\footnotetext{
${ }^{26}$ In another experiment reported in Keane and Merlo (2007), we completely eliminate the value of congressional experience in post-congressional employment. The results are for the most part very similar to the experiment of eliminating the option of entering the private sector. The reason for this similarity is that is that experience returns are much greater in the private sector than in the public sector. But an interesting aspect of this policy is that it has a much larger effect on Republicans than on Democrats. For Republicans the average duration of a political career increases by 0.61 years (from 9.10 to 9.71 years), while for Democrats it increases by only 0.14 years (from 10.06 to 10.20). The reason is that, under the baseline, post-congressional experience returns are greater for Republicans than Democrats. This is not because they have different parameters in the wage function (which, again, are the same for all types) but rather because Republicans are less likely to retire after leaving Congress than Democrats (13\% vs. 17\%).
} 
House derive from it being a stepping-stone to other prestigious offices such as governorships, judgeships, cabinet posts or even the presidency?" In general, we find the effects of preventing politicians from holding other political offices after leaving Congress are much smaller than the effects of preventing them from working in the private sector. Thus, it appears that the option of post-congressional political employment has less influence on the career decisions of members of Congress than does the option of post-congressional private sector employment.

\subsection{Policies that Change Monetary and Non-Monetary Payoffs inside and outside Congress}

In the second group of experiments we consider policies that affect relative wages and other rewards to politicians within vs. outside Congress. We primarily consider two policies, which are: 2a) eliminating congressional pensions, 2 b) a $20 \%$ decrease in the congressional wage.

Experiment $2 a$ (NOPEN): First, we consider an experiment in which we eliminate congressional pensions. This reduces the average length of a political career by almost half a year (from 9.61 to 9.14 years - see Table 1), which is a larger effect on average career length than any policy we have considered so far. The effect is about three times greater for skilled than unskilled politicians (i.e., 0.77 years vs. 0.25 years). Of course, the effect is much greater for politicians who are young at entry. It is about the same for achievers and non-achievers, but about twice as great for Democrats (0.61 years) than Republicans (0.31 years). The larger effect for Democrats stems at least in part from the fact that, under the baseline, they are 4 percentage points more likely than Republicans to completely retire after leaving Congress (see Table 5). ${ }^{27}$

Note that abolishing pensions actually increases the value of a congressional seat slightly see Table 4. This may seem unintuitive, but, as noted earlier, it makes sense given that the value of a seat is defined as the monetary payment required to make a member indifferent between staying in Congress vs. exiting. Eliminating pensions does reduce the value of continuing in Congress, but it reduces the value of exit even more. Finally, as we see in Table 5, the probability a politician completely retires after leaving Congress is greatly reduced, from $15.5 \%$ to only $4.9 \%$. The increase in public sector employment (5.6 points) is slightly larger than for private employment (5.1 points).

\footnotetext{
${ }^{27}$ In results reported in Keane and Merlo (2007), we find that eliminating pensions has no effect on career length for those from political families or with no prior political experience. The decline is concentrated among those who held prior political office or come from non-political families. This is consistent with the conjecture that these individuals are more likely to view politics as a vocation (rather than an avocation), in Weber's terminology, or to have political careers (rather than being career politicians), in Mattozzi and Merlo's terminology. Those who view politics as a vocation are more concerned with monetary rewards, such as retirement benefits. As noted in Section 2.6, however, this result should be viewed with caution, as the parameters mapping these background characteristics to type are not precisely estimated.
} 
In summary, reducing pensions induces earlier exit from Congress by politicians who are more skilled, younger at entry or members of the Democratic Party. But there is little differential impact on achievers vs. non-achievers. ${ }^{28}$

Experiment $2 \boldsymbol{b}$ (CWAGEDECR): Second, we consider an experiment in which we reduce the congressional wage by $20 \%$. This induces a far greater drop in average length of a congressional career than any policy we have yet considered. According to Table 1, average career duration drops by 1.34 years (from 9.61 to 8.27 ). This policy reduces the value of seat in the House from $\$ 616,228$ to $\$ 491,905$ (or $20 \%$ ), but it only reduces the value of a seat in the Senate from $\$ 1,673,762$ to $\$ 1,512,592$ (or $10 \%$ ) - see Table 4 . The difference arises because a much larger fraction of the rewards to sitting in the Senate are non-pecuniary. Consistent with these figures, the probability a House member runs for re-election drops from $91.23 \%$ to $86.69 \%$ (see Table 2); viewed another way, the probability of not running for re-election increases by about $50 \%$ (from $8.77 \%$ to $13.31 \%$ ).

Qualitatively, the effects of reducing salaries on different groups are quite similar to the effects of eliminating pensions. This is not surprising, as pensions are just deferred compensation. Again the effect is about three times greater for skilled than unskilled politicians (i.e., 2.25 years vs. 0.84 years $).{ }^{29}$ As with pensions, the effect is much greater for those politicians who are younger at entry, and almost twice as great for Democrats (1.70 years) as Republicans (0.93 years).

Again as with pensions, the effect of reducing congressional wages is about the same for achievers and non-achievers. This, along with the finding that the effect is much greater for skilled politicians, represent our main empirical results germane to the theoretical literature discussed in the introduction, which looks at effects of congressional wages on the type composition of elected officials. Specifically, our results imply that reduced monetary payoffs (either wages or pensions) from serving in Congress will: (i) not disproportionately encourage achievers - i.e., those who value legislative accomplishments - to leave Congress, but will (ii) disproportionately encouraging skilled politicians - i.e., those who are relatively good at winning elections - to leave Congress. Thus, if one accepts that the "quality" of politicians is better represented by their ability to legislate, rather than their ability to win, our results suggest that wage reductions would not disproportionately induce high quality politicians to leave Congress.

\footnotetext{
${ }^{28}$ While it is intuitive that elimination of pensions would cause people to leave Congress sooner, there are no specific model parameters that would indicate how the effect differs by type. Simulation of the model is necessary to reveal these differences. The same holds true for the wage policy experiment we discuss next, as there are no parameters in the model that explicitly allow wage effects to differ by type.

${ }^{29}$ Note that the value of a House seat falls by $\$ 133,000$ for the skilled type, but only $\$ 109,000$ for the unskilled type.
} 
Interestingly, the $20 \%$ drop in congressional wages leads to a substantial reduction in the fraction of politicians who retire after leaving Congress, from $15.5 \%$ to $10 \%$ (see Table 5). This occurs largely because politicians are now simply younger (by 1.34 years) when they leave office, and in part because pensions will now be lower. There is also an increase in the frequency of voluntarily leaving Congress from $6.7 \%$ to $10.3 \%$ (see Table 2) - that is, a higher proportion of leavers do so voluntarily rather than due to electoral defeat.

Notably, the drop in voluntary retirement upon leaving Congress is much greater among skilled politicians (from $27 \%$ to $17 \%$ ) than unskilled politicians (from $7.5 \%$ to $5 \%$ ). This is because, under the baseline, skilled politicians rarely leave Congress via electoral defeat. Hence, they often leave Congress with the intention of completely retiring. But under the experiment, exiting to work in the private sector becomes a more attractive option. Thus, using the terminology of the prior literature discussed in the introduction, the wage reduction converts them from "career politicians" to people with "political careers."

In another experiment not reported in the tables, we eliminated congressional wages entirely. This experiment is interesting because it allows us to assess the total value of House and Senate seats that come from salary vs. all other factors. Of the $\$ 616,228$ total value of a House seat, $\$ 501,332$ comes from the expected present value of salary payments, while $\$ 114,896$ comes from utility derived from serving in Congress, including perks of office, the possibility of legislative accomplishments, increased wages after leaving Congress, etc. At first glance one might interpret the large difference in these figures to mean that House members are primarily interested in salary. But, in our view, the most remarkable aspect of the calculation is that the average value of a House seat remains positive even if salary is completely eliminated. House members would still choose to run for re-election $59 \%$ of the time even if salary were eliminated. This implies that the non-salary rewards to serving in the House are substantial. The situation is even more striking in the Senate. Of the total value of a Senate seat, only $\$ 737,377$ comes from the expected present value of salary, while $\$ 936,386$ comes from non-salary rewards. Senators would still choose to run for re-election $75 \%$ of the time even if salary were eliminated.

In a related point, DKM estimate that part of the non-pecuniary reward from serving in Congress comes from legislative achievements. To assess the importance of this factor we also ran an experiment (see Keane and Merlo (2007) for details) where we eliminated the possibility of important legislative accomplishments. This reduces the value of a seat for achievers in the House 
by $\$ 68,000$ (or $10 \%$ ), and for achievers in the Senate by $\$ 265,000$ (or $15 \%$ ). Thus, for the achiever type, rewards from achievements are a significant part of overall non-pecuniary rewards.

\subsection{Policies that Limit Opportunities for Re-election}

The third and final group of experiments we consider pertains to policies that limit chances for re-election. We consider two policies, which are: 3a) eliminating the seniority advantage in congressional elections, and $3 \mathrm{~b}$ ) imposing term limits, with a maximum of 4 terms in the House and 2 in the Senate. The results of these experiments are again reported in Tables 1 through 5.

Experiment 3a (NOELECSENIOR): According to DKM's estimates, in the House, seniority substantially increases the probability of victory in elections, even after controlling for political skill. ${ }^{30}$ The causal effect of seniority on probability of election may arise through several channels. First, members of Congress tend to accumulate more power with greater seniority. This enables them to gain more spending earmarked for their districts, which gives voters an incentive to return them to office even if they have disagreements on policy. It also makes it easier for the politician to raise money for election campaigns. Second, there may simply be a learning effect: with experience, the politician may become better at running campaigns or raising campaign funds. Third, with time a politician may acquire more connections and more control over the local political apparatus. Such factors would again help with fundraising, get-out-the-vote efforts, and so on.

Of course, eliminating the seniority advantage is an experiment that cannot be implemented in reality. However, it is nevertheless of some policy interest, as there do exist several serious proposals for campaign reform that would potentially reduce the advantage of more senior politicians. These include campaign finance reform, spending limits, requirements for equal media access, etc.. Experiment 3a can at least shed some light on the qualitative impact of such proposals on decisions of incumbent members of Congress. ${ }^{31}$

As we see in Table 1, eliminating the seniority advantage reduces the average duration of a congressional career by 1.35 years, almost identical to the effect of the $20 \%$ congressional wage reduction. Interestingly, this does not occur by lowering the probability of running for re-election to the House. In fact, this probability actually rises slightly (by 0.1 points - see Table 2), primarily because the probability of running for Senate falls. Without the seniority advantage, the chance of

\footnotetext{
${ }^{30}$ Note that, if one fails to control for political skill, then seniority will tend to be spuriously significant in an equation for probability of winning elections. This is because prior victories proxy for political skill.

${ }^{31}$ It is important to stress that what we call the "seniority advantage" is distinct from the "incumbency advantage." All the members of Congress in our sample are of course incumbents, so we cannot estimate the incumbency advantage. We can only estimate how it increases with seniority.
} 
winning a bid for the Senate is reduced, making politicians slightly more likely to run for re-election to the House. For members of both the House and Senate, the increase in the probability of exiting Congress voluntarily is minor. Thus, the reduction in average career length does not occur because of a behavioral response by members of Congress, but simply because of the mechanical effect that, without the seniority advantage, they are more likely to suffer electoral defeat.

Now consider the effect on different types of politicians. Most policies we have previously considered had a much larger effect on skilled than on unskilled politicians. One has to be careful about making such a comparison, because skilled politicians have much longer career durations under the baseline (12.72 vs. 7.51 years). Thus, whether an effect is "greater" for skilled politicians can depend on whether one looks at percentage or level differences. In all prior cases where we stated an effect was larger for skilled politicians, this distinction was irrelevant, because differences were so large. But that is not the case here. For skilled politicians the decline in average career length is 1.69 years or $13 \%$. For unskilled politicians the decline is 1.17 years which is $16 \%$. Thus, there is no unambiguous answer to the question of which group is most affected by the policy.

The policy has a larger effect on non-achievers (1.45 years or $16 \%)$ than achievers $(1.10$ years or $10 \%)$, on Democrats $(1.53$ years or $15 \%)$ than Republicans $(1.18$ years or $13 \%)$, and on politicians who enter Congress when under 50 (2.09 years or 19\%) than on those who enter when over $50(0.90$ years or $11 \%)$. From a policy point of view, the main result of interest here is that policies that limit seniority advantages will have a greater tendency to induce non-achiever types to leave Congress - possibly a positive aspect for such policies.

Experiment $3 \boldsymbol{b}$ (TLIMITS): Finally, we consider the impact of congressional term limits. Of course, these could be set in many ways, so as an example we consider a 4-term limit in the House and a 2-term limit in the Senate. Imposing term limits reduces the average duration of congressional career by 3.55 years (from 9.61 years to 6.06 years). The effect is much larger in the House, where the average number of terms drops from 4.49 to 2.61 , than in the Senate, where average number of terms served drops only from 2.08 to 1.56 .

The reduction in average career length is not merely a mechanical result of politicians hitting up against the term limits. There is an important behavioral response as well. The probability that a House member runs for re-election drops by 9.36 percentage points, while the probability of running for Senate or leaving Congress voluntarily both roughly double. In the Senate, the probability of 
voluntary exit increases by 55\%. These behavioral changes arise because the value of a House seat falls by $32 \%$ while that of a Senate seat falls by $21 \%$ (see Table 4 ).

Turning to differences in effects by type, we see that the reduction in average career duration is far greater for skilled politicians (5.65 years or 44\%) than for unskilled politicians (2.28 years or $30 \%$ ). This is because, under the baseline, skilled politicians rarely lose elections, and can usually leave Congress when they choose to do so. Thus, it is not surprising that term limits have a much greater impact on their career choices than those of unskilled politicians. A very interesting pattern is that imposing term limits leads to a dramatic increase in the probability that House members attempt to run for Senate. As we see in Table 2, for skilled politicians this probability increases from $4.37 \%$ to $10.71 \%$, while for unskilled politicians it increases from $1.29 \%$ to $2.65 \%$.

In contrast, term limits have similar effects on achievers and non-achievers. For the former, average career length is reduced by 3.84 years or $36 \%$, while for the latter it is reduced by 3.47 years or 37\%. Thus, term limits would not improve the "quality" composition of Congress in this sense.

But large differences emerge in other dimensions. Strikingly, the effect is much greater for Democrats (4.06 years or $40 \%$ ) than for Republicans (2.97 years or 33\%). This is because the constraint is more often binding for Democrats, who serve an average of 4.72 terms in the House under the baseline, than it is for Republicans, who serve an average of 4.21 years. After term limits are imposed politicians from $\underline{\text { both }}$ parties serve an average of exactly 2.61 House terms.

This analysis highlights a feature of term limits that to our knowledge has not been previously noted: they will always tend to favor the minority party relative to the majority party. Members of the majority party will on average have longer career durations, and therefore they will be impacted more by term limits. As we've seen, seniority increases election probabilities. Thus, term limits will force exit by senior members of the majority party more often, replacing them with new candidates who have neither an incumbency nor seniority advantage. ${ }^{32}$

Terms limits also have a much larger effect on politicians who are younger when they enter Congress. The reason is similar to why term limits have a larger effect on Democrats. Those who

\footnotetext{
${ }^{32}$ In The Federalist 51 Madison argued that term limits would diminish the power of the legislative branch relative to the executive by depriving it of its most able and experienced members, which is consistent with what we find here. But it does not appear that Madison considered the potential impact on political parties that we note here (which is unsurprising as he did not anticipate the creation of the party system). In the year after our sample ended, 1994, the Republicans finally won back control of the House while running on the "Contract with America" platform, which included as one of a ten key initiatives: "A first-ever vote on term limits to replace career politicians with citizen legislators," by which they meant a congressional resolution proposing a constitutional amendment to impose term limits. Consistent with our results, this resolution was defeated once the Republicans actually had the majority.
} 
are younger at the time of entry have longer average career durations under the baseline. Thus, they are more likely to be impacted by term limits.

Finally, looking at Table 5, we see that, not surprisingly, imposing term limits leads to a sharp decline in the fraction of politicians who retire after exiting Congress - by about 10 percentage points. There is a 3 percentage point increase in the share of private sector jobs, and a 7 point increase in the share of jobs in the public sector. Thus, imposition of congressional term limits leads to a greater tendency to transition into other types of political jobs after exiting Congress.

\section{Conclusion}

When considering the costs and benefits of policy changes that affect members of Congress - such as changes in congressional wages and pensions, limitations on post-congressional employment opportunities, campaign finance reforms designed to reduce incumbency advantages, term limits, etc. - it is important to consider how such policies would affect their decision making. Of particular interest is whether such policies might lead to different behavioral responses by different types of politicians. For example, in the theoretical literature, there has been interest in the question of how increases in congressional salaries would affect the "quality" of members of Congress (with "quality" defined in various different ways) - see, e.g., Besley (2004), Caselli and Morelli (2004), Messner and Polborn (2004), Mattozzi and Merlo (2008).

In this paper, we have provided a quantitative analysis of the effects of a variety of policies that affect the costs and benefits from serving in the U.S. Congress on career decisions of politicians. We conduct the analysis using the empirical framework of Diermeier, Keane and Merlo (2005). In their model, members of Congress consider several factors when deciding whether to run for re-election or higher office, including congressional salaries, non-pecuniary rewards from sitting in Congress (including perks of office, utility from legislative accomplishments, etc.), and effects of congressional experience on post-congressional employment opportunities.

One of our main results concerns the effects of changes in congressional wages. We find that a $20 \%$ reduction in the congressional wage disproportionately induces skilled politicians to exit Congress - where by a "skilled" politician we mean one who is effective at winning elections. The effect of a wage reduction is also relatively large for Democrats and members who were relatively young when first elected to Congress.

However, when considering the "quality" of politicians, we argue that a more important consideration than "skill" is whether they are the "achiever" type - that is, the type that values and is 
effective at securing significant legislative accomplishments (i.e., significant legislation, important investigations, etc.). Note that a salary reduction does not cause the achiever type to disproportionately exit Congress. Thus, referring to the theoretical papers on the impact of salary noted above, our conclusion is that salary does not differentially impact the career decisions of high vs. low quality members of Congress, although it does affect skilled politicians relatively more.

However, we do find three types of policy changes that would disproportionately induce non-achievers to leave (or achievers to stay) in the Congress. These are policies that would (i) eliminate seniority as a determinant of key committee assignments, (ii) restrict private sector employment after leaving Congress, or (iii) reduce the seniority advantage in elections. An example of (ii) would be restricting former members of Congress from working as lobbyists, while examples of (iii) would be various types of campaign finance reform that reduce the fundraising advantages of incumbents (e.g., public finance, spending limits, etc). Our analysis suggests that these types of policies would tend to tip the composition of Congress towards achiever types, by increasing their continuation probabilities relative to those of non-achievers. ${ }^{33}$

Two other results are worth commenting on. First, we find that term limits would have similar effects on achiever and non-achiever types. Thus, they would not help to improve the quality composition of Congress in this sense. ${ }^{34}$ Second, we find that term limits would disproportionately reduce the continuation probabilities of members of the majority party (Democrats during our sample period). This has the interesting implication (to our knowledge not previously noted) that term limits would make it more difficult to sustain substantial congressional majorities over time. ${ }^{35}$

While our analysis extends and generalizes most of the existing empirical literature on the study of political careers, there are several important issues we have neglected to address in this paper, and which represent possible directions for future research. One issue concerns the initial decisions of politicians to run for Congress, or more broadly, the decisions of people to become

\footnotetext{
${ }^{33}$ The "continuation probability" is a composite of the probability of seeking re-election and probability of winning.

${ }^{34}$ A limitation of our analysis is that, while we predict that term limits would not disproportionately induce either the achiever or non-achiever type to exit Congress, we do not analyze how shorter terms would affect the ability of the achievers to realize achievements. Presumably, their ability to realize achievements would decline, consistent with Madison's arguments against term limits in The Federalist 51, 53. Indeed, the DKM estimates imply that seniority is a significant predictor of achievement in both the House and Senate.

${ }^{35}$ It is notable that our results could not be inferred from the estimates in DKM, as none of their model parameters are type specific - uncovering type differences requires simulation of the model.
} 
politicians. Progress on successfully addressing this question critically hinges on the collection of new data on the pool of potential candidates for public offices. ${ }^{36}$

Another important issue concerns the role of fundraising and campaigning in political careers. The seniority advantage in elections presumably represents, at least in part, the campaign fundraising advantage of more senior members of Congress. An extension of our model which incorporates fundraising explicitly could, for example, be used to address the interesting question of whether the intense fundraising and campaigning necessary to run for Congress serves as a deterrent to "public spirited" politicians, leading to adverse selection of "political dealmakers" who are beholden to lobbyists and special interests. Such a model could also be used to assess the potential effects of various campaign finance reforms like those that have recently been proposed (or struck down) in the U.S.

\footnotetext{
${ }^{36}$ The extent of this limitation should not be exaggerated however. The steady state representation of a given type (e.g. achievers) in Congress depends both on their continuation probability (one minus the exit probability) and their entry probability. In our analysis, we have calculated continuation probabilities but not entry probabilities. However, the two probabilities will usually (though not always) be closely linked. That is, a policy that increases the value of a seat in Congress will typically increase both the continuation probability of existing members and the attractiveness of running for Congress in the first place. The exceptions to this general principle are policies that restrict the options or rewards of politicians upon exit from Congress. As we saw in experiments $1 \mathrm{~b}$ and $2 \mathrm{a}$, which restricted private sector employment and eliminated pensions, respectively, such policies increase the value of holding on to a seat in Congress by reducing the value of the exit option. But they reduce the value of attaining a seat in Congress in the first place.
} 


\section{REFERENCES}

Besley, Timothy, 2004. "Paying Politicians: Theory and Evidence." Journal of the European Economic Association, 2, 193-215.

Caselli, Francesco, and Massimo Morelli, 2004. "Bad Politicians," Journal of Public Economics, $88,759-782$.

Dal Bo, Ernesto, Dal Bo, Pedro and Jason Snyder, 2008. "Political Dynasties," Review of Economic Studies, forthcoming.

Deering, Christopher J. and Steven S. Smith. 1990. Committees in Congress. Washington, DC: Congressional Quarterly Press.

Diermeier, Daniel, Keane, Michael and Antonio Merlo. 2004. "A Political Economy Model of Congressional Careers: Supplementary Material" PIER Working paper 04-38, University of Pennsylvania.

Diermeier, Daniel, Keane, Michael, and Antonio Merlo, 2005. "A Political Economy Model of Congressional Careers," American Economic Review, 95, 347-373.

Gerth, H. H., and C. Wright Mills, 1946. From Max Weber: Essays in Sociology. New York: Oxford University Press.

Groseclose, Timothy, and Keith Krehbiel. 1994. "Golden Parachutes, Rubber Checks, and Strategic Retirements from the 102nd House." American Journal of Political Science 38: 75-99.

Groseclose, Timothy and Jeff Milyo. 1999. "Buying the Bums Out: What's the Dollar Value of a Seat in Congress?" mimeo. Graduate School of Business, Stanford University.

Hall, Richard L., and Robert van Houteling. 1995. "Avarice and Ambition in Congress: Representatives' Decisions to Run or Retire from the U.S. House". American Political Science Review 89: 121-136.

Hibbing, John R. 1991. Congressional Careers: Contours of Life in the U.S. House of Representatives. Chapel Hill, NC: University of North Carolina Press.

Keane, Michael and Antonio Merlo, 2007. "Money, Political Ambition, and the Career Decisions of Politicians." PIER Working Paper 07-016, Department of Economics, University of Pennsylvania.

Kiewiet, D. Roderick, and Langche Zeng. 1993. "An Analysis of Congressional Career Decisions, 1947-1986.” American Political Science Review 87: 928-944.

Mattozzi, Andrea, and Antonio Merlo, 2008. "Political Careers or Career Politicians?" Journal of Public Economics, 92, 597-608.

Mayhew, David R. 2000. America's Congress: Actions in the Public Sphere, James Madison Through Newt Gingrich. New Haven, Conn.: Yale University Press. 
Merlo, Antonio. 2006. "Whither Political Economy? Theories, Facts and Issues." In Advances in Economics and Econometrics, Theory and Applications: Ninth World Congress of the Econometric Society, ed. Richard Blundell, Whitney Newey and Torsten Persson, Vol. 1, 381-42. Cambridge: Cambridge University Press.

Messner, Matthias, and Mattias Polborn, 2004. "Paying Politicians," Journal of Public Economics, $88,2423-2445$.

Schlesinger, Joseph. 1966. Ambition in Politics: Political Careers in the United States. Chicago: Rand McNally.

Sinclair, Barbara. 1989. The Transformation of the U.S. Senate. Baltimore: Johns Hopkins University Press. 
Table 1: Duration of Congressional Careers

\begin{tabular}{|c|c|c|c|c|c|c|c|}
\hline $\begin{array}{l}\text { Politicians' } \\
\text { characteristics }\end{array}$ & Baseline & $\begin{array}{c}1 \mathrm{a}- \\
\text { NOCOM } \\
\text { SENIOR }\end{array}$ & $\begin{array}{c}1 \mathrm{~b}- \\
\text { NOPRIV }\end{array}$ & $\begin{array}{c}2 \mathrm{a}- \\
\text { NOPEN }\end{array}$ & $\begin{array}{c}\mathrm{b}- \\
\text { CWAGE } \\
\text { DECR }\end{array}$ & $\begin{array}{c}\mathrm{a}- \\
\text { NOELEC } \\
\text { SENIOR }\end{array}$ & $\begin{array}{c}3 \mathrm{~b}- \\
\text { TLIMIT }\end{array}$ \\
\hline \multicolumn{8}{|c|}{ Average Duration of Career in Congress (Years) } \\
\hline All & 9.61 & 9.59 & 9.94 & 9.14 & 8.27 & 8.26 & 6.06 \\
\hline Skilled & 12.72 & 12.76 & 13.81 & 11.95 & 10.47 & 11.03 & 7.07 \\
\hline Non skilled & 7.51 & 7.45 & 7.45 & 7.26 & 6.67 & 6.34 & 5.23 \\
\hline Achiever & 10.56 & 10.73 & 11.05 & 10.13 & 9.27 & 9.46 & 6.72 \\
\hline Non achiever & 9.29 & 9.19 & 9.56 & 8.81 & 7.93 & 7.84 & 5.82 \\
\hline Democrat & 10.06 & 9.99 & 10.37 & 9.45 & 8.36 & 8.53 & 6.00 \\
\hline Republican & 9.10 & 9.11 & 9.43 & 8.79 & 8.17 & 7.92 & 6.13 \\
\hline Age at entry $<50$ & 10.78 & 10.65 & 11.34 & 10.09 & 9.04 & 9.11 & 6.46 \\
\hline Age at entry $\geq 50$ & 7.93 & 8.04 & 8.01 & 7.79 & 7.14 & 7.03 & 5.44 \\
\hline \multicolumn{8}{|c|}{ Average Duration of Career in House of Representatives (Terms) } \\
\hline All & 4.49 & 4.44 & 4.68 & 4.22 & 3.73 & 3.85 & 2.61 \\
\hline Skilled & 5.86 & 5.79 & 6.50 & 5.44 & 4.62 & 5.23 & 2.92 \\
\hline Non skilled & 3.54 & 3.53 & 3.51 & 3.40 & 3.07 & 2.90 & 2.37 \\
\hline Achiever & 4.71 & 4.80 & 4.98 & 4.44 & 3.90 & 4.19 & 2.67 \\
\hline Non achiever & 4.42 & 4.34 & 4.59 & 4.16 & 3.68 & 3.76 & 2.60 \\
\hline Democrat & 4.72 & 4.64 & 4.92 & 4.36 & 3.79 & 3.95 & 2.61 \\
\hline Republican & 4.21 & 4.21 & 4.39 & 4.05 & 3.66 & 3.73 & 2.61 \\
\hline Age at entry $<50$ & 4.98 & 4.87 & 5.31 & 4.57 & 4.00 & 4.23 & 2.71 \\
\hline Age at entry $\geq 50$ & 3.78 & 3.83 & 3.81 & 3.71 & 3.32 & 3.32 & 2.47 \\
\hline \multicolumn{8}{|c|}{ Average Duration of Career in Senate (Terms) } \\
\hline All & 2.08 & 2.08 & 2.15 & 2.05 & 2.00 & 2.10 & 1.56 \\
\hline Skilled & 2.40 & 2.39 & 2.52 & 2.25 & 2.20 & 2.41 & 1.62 \\
\hline Non skilled & 1.78 & 1.76 & 1.82 & 1.84 & 1.79 & 1.87 & 1.47 \\
\hline Achiever & 2.15 & 2.16 & 2.28 & 2.13 & 2.08 & 2.19 & 1.58 \\
\hline Non achiever & 2.00 & 2.01 & 2.01 & 1.96 & 1.92 & 1.99 & 1.54 \\
\hline Democrat & 2.13 & 2.22 & 2.24 & 2.22 & 2.07 & 2.29 & 1.57 \\
\hline Republican & 2.02 & 1.93 & 2.05 & 1.86 & 1.93 & 1.88 & 1.55 \\
\hline Age at entry $<50$ & 2.22 & 2.25 & 2.36 & 2.20 & 2.14 & 2.30 & 1.61 \\
\hline Age at entry $\geq 50$ & 1.80 & 1.77 & 1.80 & 1.75 & 1.75 & 1.77 & 1.45 \\
\hline
\end{tabular}


Table 2: Decisions of Representatives

\begin{tabular}{|c|c|c|c|c|c|c|c|}
\hline $\begin{array}{l}\text { Politicians' } \\
\text { characteristics }\end{array}$ & Baseline & $\begin{array}{c}1 \mathrm{a}- \\
\text { NOCOM } \\
\text { SENIOR }\end{array}$ & $\begin{array}{c}1 \mathrm{~b}- \\
\text { NOPRIV }\end{array}$ & $\begin{array}{c}2 \mathrm{a}- \\
\text { NOPEN }\end{array}$ & $\begin{array}{c}2 \mathrm{~b}- \\
\mathrm{CWAG} \\
\text { EDECR }\end{array}$ & $\begin{array}{c}\mathrm{a}- \\
\text { NOELEC } \\
\text { SENIOR }\end{array}$ & $\begin{array}{c}3 \mathrm{~b}- \\
\text { TLIMIT }\end{array}$ \\
\hline \multicolumn{8}{|c|}{ Run for Re-Election to the House (percentage) } \\
\hline All & 91.23 & 90.96 & 92.45 & 91.29 & 86.69 & 91.37 & 81.87 \\
\hline Skilled & 91.05 & 90.68 & 93.28 & 91.37 & 86.39 & 91.91 & 81.17 \\
\hline Non skilled & 91.48 & 91.33 & 91.21 & 91.17 & 87.06 & 90.54 & 82.58 \\
\hline Achiever & 92.27 & 92.03 & 93.87 & 92.34 & 88.29 & 92.67 & 82.57 \\
\hline Non achiever & 90.90 & 90.60 & 91.96 & 90.93 & 86.16 & 90.93 & 81.66 \\
\hline Democrat & 91.48 & 91.28 & 92.66 & 91.54 & 86.67 & 91.48 & 82.00 \\
\hline Republican & 90.88 & 90.52 & 92.14 & 90.94 & 86.70 & 91.21 & 81.72 \\
\hline Age at entry $<50$ & 91.57 & 91.21 & 93.20 & 91.53 & 86.70 & 92.12 & 82.00 \\
\hline Age at entry $\geq 50$ & 90.56 & 90.48 & 90.83 & 90.81 & 86.65 & 89.88 & 81.67 \\
\hline \multicolumn{8}{|c|}{ Run for the Senate (percentage, conditional on option available) } \\
\hline All & 3.07 & 3.30 & 1.76 & 3.37 & 4.58 & 1.81 & 6.69 \\
\hline Skilled & 4.37 & 4.84 & 2.58 & 4.76 & 6.73 & 2.40 & 10.71 \\
\hline Non skilled & 1.29 & 1.24 & 0.54 & 1.51 & 1.86 & 0.91 & 2.65 \\
\hline Achiever & 4.03 & 4.04 & 2.02 & 4.11 & 5.73 & 2.15 & 8.28 \\
\hline Non achiever & 2.75 & 3.05 & 1.67 & 3.12 & 4.20 & 1.69 & 6.20 \\
\hline Democrat & 2.75 & 2.99 & 1.45 & 2.95 & 4.21 & 1.65 & 6.13 \\
\hline Republican & 3.51 & 3.71 & 2.20 & 3.94 & 5.07 & 2.02 & 7.38 \\
\hline Age at entry $<50$ & 3.91 & 4.14 & 2.20 & 4.27 & 5.89 & 2.21 & 8.48 \\
\hline Age at entry $\geq 50$ & 1.39 & 1.66 & 0.81 & 1.62 & 2.17 & 1.00 & 3.72 \\
\hline \multicolumn{8}{|c|}{ Exit Congress Voluntarily (percentage) } \\
\hline All & 6.73 & 6.85 & 6.39 & 6.48 & 10.27 & 7.44 & 13.69 \\
\hline Skilled & 6.04 & 6.09 & 5.01 & 5.46 & 9.11 & 6.49 & 11.71 \\
\hline Non skilled & 7.66 & 7.85 & 8.44 & 7.83 & 11.72 & 8.86 & 15.67 \\
\hline Achiever & 5.04 & 5.28 & 4.79 & 4.92 & 7.90 & 5.90 & 11.90 \\
\hline Non achiever & 7.28 & 7.38 & 6.93 & 7.00 & 11.05 & 7.96 & 14.24 \\
\hline Democrat & 6.69 & 6.73 & 6.38 & 6.50 & 10.53 & 7.43 & 13.95 \\
\hline Republican & 6.79 & 7.02 & 6.40 & 6.44 & 9.94 & 7.45 & 13.38 \\
\hline Age at entry $<50$ & 5.83 & 6.04 & 5.33 & 5.62 & 9.37 & 6.42 & 12.35 \\
\hline Age at entry $\geq 50$ & 8.51 & 8.43 & 8.63 & 8.12 & 11.91 & 9.46 & 15.89 \\
\hline
\end{tabular}


Table 3: Decisions of Senators

\begin{tabular}{|c|c|c|c|c|c|c|c|}
\hline $\begin{array}{l}\text { Politicians' } \\
\text { characteristics }\end{array}$ & Baseline & $\begin{array}{c}1 \mathrm{a}- \\
\text { NOCOM } \\
\text { SENIOR }\end{array}$ & $\begin{array}{c}1 \mathrm{~b}- \\
\text { NOPRIV }\end{array}$ & $\begin{array}{c}2 \mathrm{a}- \\
\text { NOPEN }\end{array}$ & $\begin{array}{c}2 \mathrm{~b}- \\
\text { CWAG } \\
\text { EDECR }\end{array}$ & $\begin{array}{c}\mathrm{a}- \\
\text { NOELEC } \\
\text { SENIOR }\end{array}$ & $\begin{array}{c}3 \mathrm{~b}- \\
\text { TLIMIT }\end{array}$ \\
\hline \multicolumn{8}{|c|}{ Run for Re-Election to the Senate (percentage) } \\
\hline All & 85.24 & 84.57 & 86.55 & 84.32 & 82.31 & 83.89 & 77.09 \\
\hline Skilled & 87.48 & 86.62 & 89.12 & 85.58 & 84.14 & 84.90 & 78.48 \\
\hline Non skilled & 81.55 & 80.94 & 82.63 & 82.29 & 79.20 & 82.64 & 75.10 \\
\hline Achiever & 86.86 & 85.49 & 87.13 & 86.66 & 84.03 & 85.67 & 78.47 \\
\hline Non achiever & 83.27 & 83.53 & 85.83 & 81.36 & 80.20 & 81.49 & 75.74 \\
\hline Democrat & 85.44 & 84.63 & 87.30 & 85.87 & 82.96 & 84.41 & 77.16 \\
\hline Republican & 84.98 & 84.50 & 85.60 & 82.19 & 81.52 & 83.14 & 77.01 \\
\hline Age at entry $<50$ & 86.66 & 85.95 & 88.00 & 85.68 & 83.83 & 85.80 & 77.50 \\
\hline Age at entry $\geq 50$ & 81.19 & 80.54 & 82.70 & 80.26 & 78.00 & 79.17 & 76.15 \\
\hline \multicolumn{8}{|c|}{ Exit Congress Voluntarily (percentage) } \\
\hline All & 14.76 & 15.43 & 13.45 & 15.68 & 17.69 & 16.11 & 22.91 \\
\hline Skilled & 12.52 & 13.38 & 10.88 & 14.42 & 15.86 & 15.10 & 21.52 \\
\hline Non skilled & 18.45 & 19.06 & 17.37 & 17.71 & 20.80 & 17.36 & 24.90 \\
\hline Achiever & 13.14 & 14.51 & 12.87 & 13.34 & 15.97 & 14.33 & 21.53 \\
\hline Non achiever & 16.73 & 16.47 & 14.17 & 18.64 & 19.80 & 18.51 & 24.26 \\
\hline Democrat & 14.56 & 15.37 & 12.70 & 14.13 & 17.04 & 15.59 & 22.84 \\
\hline Republican & 15.02 & 15.50 & 14.40 & 17.81 & 18.48 & 16.86 & 22.99 \\
\hline Age at entry $<50$ & 13.34 & 14.05 & 12.00 & 14.32 & 16.17 & 14.20 & 22.50 \\
\hline Age at entry $\geq 50$ & 18.81 & 19.46 & 17.30 & 19.74 & 22.00 & 20.83 & 23.85 \\
\hline
\end{tabular}


Table 4: Value of a Congressional Seat

\begin{tabular}{lccccccc}
\hline $\begin{array}{l}\text { Politicians' } \\
\text { characteristics }\end{array}$ & Baseline & $\begin{array}{c}1 \mathrm{a}- \\
\text { NOCOM } \\
\text { SENIOR }\end{array}$ & $\begin{array}{c}\text { 1b - } \\
\text { NOPRIV }\end{array}$ & $\begin{array}{c}\text { 2a - } \\
\text { NOPEN }\end{array}$ & $\begin{array}{c}\text { 2b - } \\
\text { CWAGE } \\
\text { DECR }\end{array}$ & $\begin{array}{c}\text { 3a- } \\
\text { NOELEC } \\
\text { SENIOR }\end{array}$ & $\begin{array}{c}\text { Tb - } \\
\text { TLIMIT }\end{array}$ \\
\hline All & \multicolumn{7}{c}{ Average Value of a House Seat } \\
Skilled & 616,228 & 615,054 & 663,271 & 621,229 & 491,905 & 590,461 & 418,322 \\
Non skilled & 658,294 & 657,063 & 731,413 & 670,413 & 525,335 & 631,145 & 459,528 \\
Achiever & 559,425 & 559,796 & 562,384 & 555,799 & 450,260 & 529,012 & 377,329 \\
Non achiever & 683,641 & 674,351 & 736,852 & 693,991 & 547,764 & 641,860 & 454,913 \\
Democrat & 594,434 & 595,291 & 638,152 & 596,657 & 473,666 & 573,029 & 407,156 \\
Republican & 615,100 & 616,817 & 667,595 & 625,874 & 491,973 & 593,432 & 413,282 \\
Age at entry $<50$ & 617,820 & 612,621 & 657,198 & 614,935 & 491,815 & 586,424 & 424,561 \\
Age at entry $\geq 50$ & 642,337 & 640,247 & 698,052 & 645,559 & 511,502 & 617,187 & 439,937 \\
& 564,593 & 566,140 & 588,904 & 574,190 & 456,130 & 537,165 & 383,023 \\
\hline All & $1,673,763$ & $1,665,688$ & $1,786,820$ & $1,690,264$ & $1,512,592$ & $1,656,759$ & $1,322,786$ \\
Skilled & $1,746,769$ & $1,732,713$ & $1,910,486$ & $1,776,338$ & $1,577,629$ & $1,766,851$ & $1,358,170$ \\
Non skilled & $1,552,792$ & $1,545,791$ & $1,596,454$ & $1,549,178$ & $1,401,954$ & $1,520,961$ & $1,272,205$ \\
Achiever & $1,809,194$ & $1,800,580$ & $1,918,397$ & $1,823,722$ & $1,640,940$ & $1,767,954$ & $1,404,629$ \\
Non achiever & $1,514,395$ & $1,514,068$ & $1,626,597$ & $1,525,987$ & $1,359,484$ & $1,510,736$ & $1,244,806$ \\
Democrat & $1,722,419$ & $1,703,866$ & $1,846,288$ & $1,742,997$ & $1,564,965$ & $1,696,018$ & $1,350,436$ \\
Republican & $1,612,571$ & $1,617,777$ & $1,711,810$ & $1,618,119$ & $1,448,578$ & $1,601,973$ & $1,292,327$ \\
Age at entry $<50$ & $1,734,115$ & $1,725,209$ & $1,874,790$ & $1,751,424$ & $1,561,343$ & $1,719,998$ & $1,346,143$ \\
Age at entry $\geq 50$ & $1,506,437$ & $1,498,666$ & $1,556,500$ & $1,512,810$ & $1,378,131$ & $1,507,517$ & $1,271,359$
\end{tabular}


Table 5: Post-Congressional Career Decisions

\begin{tabular}{|c|c|c|c|c|c|c|c|}
\hline $\begin{array}{l}\text { Politicians' } \\
\text { characteristics }\end{array}$ & Baseline & $\begin{array}{c}1 \mathrm{a}- \\
\text { NOCOM } \\
\text { SENIOR }\end{array}$ & $\begin{array}{c}1 \mathrm{~b}- \\
\text { NOPRIV }\end{array}$ & $\begin{array}{c}2 \mathrm{a}- \\
\text { NOPEN }\end{array}$ & $\begin{array}{c}2 \mathrm{~b}- \\
\mathrm{CWAG} \\
\mathrm{EDECR}\end{array}$ & $\begin{array}{c}\mathrm{a}- \\
\text { NOELEC } \\
\text { SENIOR }\end{array}$ & $\begin{array}{c}3 \mathrm{~b}- \\
\text { TLIMIT }\end{array}$ \\
\hline \multicolumn{8}{|c|}{ Percentage that Choose the Private Sector (Upon Exit From Congress) } \\
\hline All & 48.64 & 48.86 & na & 53.70 & 50.67 & 50.53 & 51.69 \\
\hline Skilled & 44.23 & 45.97 & na & 54.04 & 48.27 & 47.80 & 51.76 \\
\hline Non skilled & 51.64 & 50.81 & na & 53.48 & 52.43 & 52.42 & 51.63 \\
\hline Achiever & 49.87 & 50.57 & na & 54.58 & 52.33 & 51.47 & 53.17 \\
\hline Non achiever & 48.22 & 48.27 & na & 53.41 & 50.10 & 50.21 & 51.15 \\
\hline Democrat & 47.58 & 48.07 & na & 54.20 & 52.17 & 49.32 & 51.67 \\
\hline Republican & 49.90 & 49.78 & na & 53.13 & 48.86 & 51.97 & 51.71 \\
\hline Age at entry $<50$ & 49.24 & 49.88 & na & 54.13 & 52.42 & 51.80 & 52.73 \\
\hline Age at entry $\geq 50$ & 47.79 & 47.38 & na & 53.10 & 48.08 & 48.70 & 50.10 \\
\hline \multicolumn{8}{|c|}{ Percentage that Choose the Public Sector (Upon Exit From Congress) } \\
\hline All & 35.83 & 36.59 & 71.10 & 41.40 & 39.25 & 38.74 & 42.46 \\
\hline Skilled & 28.54 & 28.65 & 52.51 & 38.22 & 34.98 & 32.35 & 39.65 \\
\hline Non skilled & 40.78 & 41.96 & 83.07 & 43.53 & 42.37 & 43.17 & 44.76 \\
\hline Achiever & 35.60 & 34.95 & 71.56 & 41.34 & 38.23 & 38.14 & 43.26 \\
\hline Non achiever & 35.91 & 37.16 & 70.95 & 41.42 & 39.60 & 38.95 & 42.17 \\
\hline Democrat & 35.09 & 35.26 & 67.93 & 40.28 & 37.08 & 38.77 & 42.17 \\
\hline Republican & 36.71 & 38.15 & 74.82 & 42.70 & 41.88 & 38.71 & 42.82 \\
\hline Age at entry $<50$ & 36.42 & 37.23 & 73.42 & 42.16 & 39.70 & 39.47 & 44.35 \\
\hline Age at entry $\geq 50$ & 34.98 & 35.67 & 67.92 & 40.31 & 38.58 & 37.70 & 39.57 \\
\hline \multicolumn{8}{|c|}{ Percentage that Retire (Upon Exit from Congress) } \\
\hline All & 15.52 & 14.55 & 28.90 & 4.90 & 10.08 & 10.73 & 5.85 \\
\hline Skilled & 27.23 & 25.39 & 47.49 & 7.74 & 16.75 & 19.85 & 8.59 \\
\hline Non skilled & 7.58 & 7.23 & 16.93 & 2.99 & 5.20 & 4.41 & 3.61 \\
\hline Achiever & 14.53 & 14.48 & 28.44 & 4.08 & 9.44 & 10.39 & 3.57 \\
\hline Non achiever & 15.87 & 14.57 & 29.05 & 5.18 & 10.30 & 10.84 & 6.68 \\
\hline Democrat & 17.33 & 16.66 & 32.07 & 5.52 & 10.75 & 11.91 & 6.17 \\
\hline Republican & 13.39 & 12.06 & 25.18 & 4.18 & 9.26 & 9.32 & 5.47 \\
\hline Age at entry $<50$ & 14.34 & 12.90 & 26.58 & 3.71 & 7.88 & 8.74 & 2.92 \\
\hline Age at entry $\geq 50$ & 17.23 & 16.95 & 32.08 & 6.59 & 13.34 & 13.59 & 10.33 \\
\hline
\end{tabular}




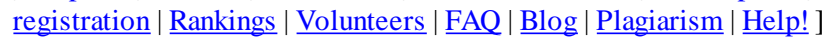

\title{
Money, Political Ambition, and the Career Decisions of Politicians
}

\section{Author Info}

\author{
$\underline{\text { Author info } \mid}|\underline{\text { Abstract }}| \underline{\text { Publisher info }}|\underline{\text { Download info }}|$ Related research $\mid$ Statistics
}

\section{Michael P. Keane \\ Antonio Merlo}

Additional information is available for the following registered author(s):

- Michael P Keane

- Antonio Merlo

\begin{abstract}
We assess the impact of a variety of policies that may influence the career decisions of members of the US Congress. These policies alter incentives to run for re-election, run for higher office or leave Congress, by altering wages, non-pecuniary rewards and career prospects (both in and out of Congress). We find that the effect of most policies varies considerably across different types of politicians. For example, a reduction in the congressional wage would disproportionately induce exit from Congress by "skilled" politicians, Democrats, and politicians who were relatively young when first elected, but not by politicians who most value legislative accomplishments ("achievers"). (JEL D72)
\end{abstract}

\section{Download Info}

To download:

If you experience problems downloading a file, check if you have the proper application to view it first. Information about this may be contained in the File-Format links below. In case of further problems read the IDEAS help page. Note that these files are not on the IDEAS site. Please be patient as the files may be large.

○ File URL: http://hdl.handle.net/10.1257/mic.2.3.186

File Format: text/html

File Function:

Download Restriction: no

File URL: http://www.aeaweb.org/articles.php?doi=10.1257/mic.2.3.186

File Format: application/pdf

File Function:

Download Restriction: Access to full text is restricted to AEA members.

File URL: http://www.aeaweb.org/aej/mic/data/2007-0001_data.zip

File Format: application/zip

File Function: dataset accompanying article

Download Restriction: no

download the selected file

\section{Publisher Info}

Article provided by American Economic Association in its journal American Economic Journal: Microeconomics.

Volume (Year): 2 (2010)

Issue (Month): 3 (August)

Pages: $186-215$

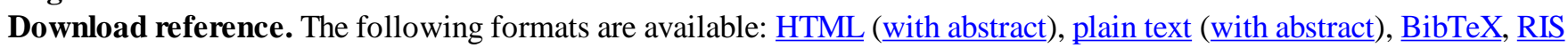
(EndNote, RefMan, ProCite), ReDIF

Handle: RePEc:aea:aejmic:v:2:y:2010:i:3:p:186-215 
Email: aeainfo@vanderbilt.edu

Web page: http://www.aeaweb.org/aej-micro

More information through EDIRC

Order Information:

Web: http://www.aeaweb.org/subscribe.html

For technical questions regarding this item, or to correct its listing, contact: ekwurzel@econlit.org (Drucilla Ekwurzel) or mpa@aeapubs.org (Michael P. Albert).

\section{Related research}

Keywords:

Other versions of this item:

- Paper

○ Michael P. Keane \& Antonio Merlo, 2007. "Money, Political Ambition, and the Career Decisions of Politicians," PIER Working Paper Archive 07-016, Penn Institute for Economic Research, Department of Economics, University of Pennsylvania. [Downloadable!

References listed on IDEAS

Please report citation or reference errors to Jose.Barrueco@uv.es, or , if you are the registered author of the cited work, log in to your RePEc Author Service profile, click on "citations" and make appropriate adjustments.:

1. Tim Groseclose \& Jeffrey Milyo, 1999. 'Buying the Bums Out: What's the Dollar Value of a Seat in Congress?," Discussion Papers Series, Department of Economics, Tufts University 9923, Department of Economics, Tufts University. [Downloadable!]

2. Ernesto Dal Bo \& Pedro Dal Bo \& Jason Snyder, . "Political Dynasties," Working Papers 2006-15, Brown University, Department of Economics. [Downloadable!] Other versions:

○ Ernesto Dal Bó \& Pedro Dal Bó \& Jason Snyder, 2007. 'Political Dynasties," NBER Working Papers 13122, National Bureau of Economic Research, Inc. [Downloadable!] (restricted)

○ ERNESTO DAL BÓ \& PEDRO DAL BÓ \& JASON SNYDER, 2009. 'Political Dynasties," Review of Economic Studies, Blackwell Publishing, vol. 76(1), pages 115-142, 01. [Downloadable!] (restricted)

3. Mattozzi, Andrea \& Merlo, Antonio, 2007. "Political Careers or Career Politicians?," CEPR Discussion Papers 6164, C.E.P.R. Discussion Papers. [Downloadable!] (restricted) Other versions:

○ Andrea Mattozzi \& Antonio Merlo, 2007. 'Political Careers or Career Politicians?," NBER Working Papers 12921, National Bureau of Economic Research, Inc. [Downloadable!] (restricted)

○ Antonio Merlo \& Andrea Mattozzi, 2005. 'Political Careers or Career Politicians?," 2005 Meeting Papers 740, Society for Economic Dynamics.

- Andrea Mattozzi \& Antonio Merlo, 2005. 'Political Careers or Career Politicians?," PIER Working Paper Archive 05-032, Penn Institute for Economic Research, Department of Economics, University of Pennsylvania, revised 01 Dec 2005. [Downloadable!]

○ Mattozzi, Andrea \& Merlo, Antonio, 2008. 'Political careers or career politicians?," Journal of Public Economics, Elsevier, vol. 92(3-4), pages 597-608, April. [Downloadable!] (restricted)

4. Messner, Matthias \& Polborn, Mattias K., 2004. 'Paying politicians," Journal of Public Economics, Elsevier, vol. 88(12), pages 2423-2445, December. [Downloadable!] (restricted)

Other versions:

○ Matthias Messner \& Mattias Polborn, 2003. 'Paying Politicians," Working Papers 246, IGIER (Innocenzo Gasparini Institute for Economic Research), Bocconi University. [Downloadable!

5. Caselli, Francesco \& Morelli, Massimo, 2004. 'Bad politicians," Journal of Public Economics, Elsevier, vol. 88(3-4), pages 759-782, March. [Downloadable!] (restricted)

Other versions:

○ Caselli, Francesco \& Morelli, Massimo, 2000. "Bad Politicians,"CEPR Discussion Papers 2402, C.E.P.R. Discussion Papers. [Downloadable!] (restricted)

- Francesco Caselli \& Massimo Morelli, 2000. 'Bad politicians," Discussion Paper / Institute for Empirical Macroeconomics 134 Federal Reserve Bank of Minneapolis. [Downloadable!]

○ Francesco Caselli \& Massimo Morelli, 2001. "Bad Politicians," NBER Working Papers 8532, National Bureau of Economic Research, Inc. [Downloadable!] (restricted)

6. Daniel Diermeier \& Michael Keane \& Antonio Merlo, 2002. "A Political Economy Model of Congressional Careers," PIER Working Paper Archive 04-037, Penn Institute for Economic Research, Department of Economics, University of Pennsylvania, revised 01 Sep 2004. [Downloadable!] Other versions:

○ Daniel Diermeier \& Michael Keane \& Antonio Merlo, 2004. "A Political Economy Model of Congressional Careers," Discussion Papers 1387, Northwestern University, Center for Mathematical Studies in Economics and Management Science. [Downloadable!]

○ Daniel Diermeier \& Michael Keane \& Antonio Merlo, 2005. "A Political Economy Model of Congressional Careers," American Economic Review, American Economic Association, vol. 95(1), pages 347-373, March. [Downloadable!]

7. Antonio Merlo, 2005. 'Whither Political Economy? Theories, Facts and Issues," PIER Working Paper Archive 05-033, Penn Institute for Economic Research, Department of Economics, University of Pennsylvania, revised 01 Dec 2005. [Downloadable!]

\section{Full references}

\section{Cited by:}

(explanations, RSS feed, Please report citation or reference errors to Jose.Barrueco@uv.es, or , if you are the registered author of the cited work, log 
in to your RePEc Author Service profile, click on "citations" and make appropriate adjustments.)

1. Andrea Mattozzi \& Antonio Merlo, 2007. 'Political Careers or Career Politicians?," NBER Working Papers 12921, National Bureau of Economic Research, Inc. [Downloadable!] (restricted) Other versions:

○ Antonio Merlo \& Andrea Mattozzi, 2005. 'Political Careers or Career Politicians?," 2005 Meeting Papers 740, Society for Economic Dynamics.

○ Andrea Mattozzi \& Antonio Merlo, 2005. "Political Careers or Career Politicians?," PIER Working Paper Archive 05-032, Penn Institute for Economic Research, Department of Economics, University of Pennsylvania, revised 01 Dec 2005. [Downloadable!]

○ Mattozzi, Andrea \& Merlo, Antonio, 2007. 'Political Careers or Career Politicians?," CEPR Discussion Papers 6164, C.E.P.R. Discussion Papers. [Downloadable!] (restricted)

- Mattozzi, Andrea \& Merlo, Antonio, 2008. "Political careers or career politicians?," Journal of Public Economics, Elsevier, vol. 92(3-4), pages 597-608, April. [Downloadable!] (restricted)

2. Gagliarducci, Stefano \& Nannicini, Tommaso \& Naticchioni, Paolo, 2008. "Outside Income and Moral Hazard: The Elusive Quest for Good Politicians," IZA Discussion Papers 3295, Institute for the Study of Labor (IZA). [Downloadable!] Other versions:

○ Gagliarducci, Stefano \& Nannicini, Tommaso \& Naticchioni, Paolo, . "Outside income and moral hazard : the elusive quest for good politicians," Open Access publications from Universidad Carlos III de Madrid info:hdl:10016/711, Universidad Carlos III de Madrid. [Downloadable!]

- Stefano Gagliarducci \& Tommaso Nannicini \& Paolo Naticchioni, 2007. "Outside income and moral hazard : the elusive quest for good politicians," Economics Working Papers we073218, Universidad Carlos III, Departamento de Economía. [Downloadable!

- Stefano Gagliarducci \& Tommaso Nannicini \& Paolo Naticchioni, 2007. "Outside Income and Moral Hazard: The Elusive Quest for Good Politicians," Boston University - Department of Economics - The Institute for Economic Development Working Papers Series dp-164, Boston University - Department of Economics. [Downloadable!]

3. Andrea Mattozzi \& Antonio Merlo, 2005. 'Political Careers or Career Politicians? Second Version," PIER Working Paper Archive 07-009, Penn Institute for Economic Research, Department of Economics, University of Pennsylvania, revised 07 Feb 2007. [Downloadable!]

4. Claudio Ferraz \& Frederico Finan, 2009. "Motivating Politicians: The Impacts of Monetary Incentives on Quality and Performance," NBER Working Papers 14906, National Bureau of Economic Research, Inc. [Downloadable!] (restricted) Other versions:

○ Ferraz, Claudio \& Finan, Frederico, 2008. "Motivating Politicians: The Impacts of Monetary Incentives on Quality and Performance," IZA Discussion Papers 3411, Institute for the Study of Labor (IZA). [Downloadable!]

$\circ$ Claudio Ferraz \& Frederico Finan, 2009. 'Motivating Politicians: The Impacts of Monetary Incentives on Quality and Performance,"Working Papers id:1889, esocialsciences.com. [Downloadable!]

5. Antonio Merlo \& Vincenzo Galasso \& Massimiliano Landi \& Andrea Mattozzi, 2008. 'the Labor Market of Italian Politicians, Second Version," PIER Working Paper Archive 09-024, Penn Institute for Economic Research, Department of Economics, University of Pennsylvania, revised 01 May 2009. [Downloadable!]

6. Stefano Gagliarducci \& Tommaso Nannicini, 2010. 'Do Better Paid Politicians Perform Better? Disentangling Incentives from Selection," CEIS Research Paper 162, Tor Vergata University, CEIS, revised 28 May 2010. [Downloadable!] Other versions:

○ Gagliarducci, Stefano \& Nannicini, Tommaso, 2009. 'Do Better Paid Politicians Perform Better? Disentangling Incentives from Selection," IZA Discussion Papers 4400, Institute for the Study of Labor (IZA). [Downloadable!]

- Stefano Gagliarducci \& Tommaso Nannicini, 2008. 'Do Better Paid Politicians Perform Better? Disentangling Incentives from Selection,"Working Papers 346, IGIER (Innocenzo Gasparini Institute for Economic Research), Bocconi University. [Downloadable!

7. Thomas Braendle \& Alois Stutzer, 2010. 'Public servants in parliament: theory and evidence on its determinants in Germany," Public Choice, Springer, vol. 145(1), pages 223-252, October. [Downloadable!] (restricted)

8. Michael P. Keane \& Kenneth I. Wolpin, 2009. "Empirical Applications of Discrete Choice Dynamic Programming Models," Review of Economic Dynamics, Elsevier for the Society for Economic Dynamics, vol. 12(1), pages 1-22, January. [Downloadable!] (restricted)

9. Andrea Mattozzi, 2008. "The Labor Market of Italian Politicians," Labor Economics Working Papers 1548, East Asian Bureau of Economic Research. [Downloadable!] Other versions:

- Antonio Merlo \& Vincenzo Galasso \& Massimiliano Landi \& Andrea Mattozzi, 2008. "The Labor Market of Italian Politicians," Working Papers 15-2008, Singapore Management University, School of Economics, revised Oct 2008. [Downloadable!]

- Antonio Merlo \& Vincenzo Galasso \& Massimiliano Landi \& Andrea Mattozzi, 2008. "The Labor Market of Italian Politicians," Carlo Alberto Notebooks 89, Collegio Carlo Alberto. [Downloadable!]

10. Facundo Albornoz \& Antonio Cabrales, 2010. "Fiscal centralization and the political process," Economics Working Papers we100402, Universidad Carlos III, Departamento de Economía. [Downloadable!]

Other versions:

○ Albornoz, Facundo \& Cabrales, Antonio, . "Fiscal centralization and the political process," Open Access publications from Universidad Carlos III de Madrid info:hdl:10016/6673, Universidad Carlos III de Madrid. [Downloadable!]

○ Albornoz-Crespo, Facundo \& Cabrales, Antonio, 2010. "Fiscal Centralization and the Political Process,"CEPR Discussion Papers 7665, C.E.P.R. Discussion Papers. [Downloadable!] (restricted)

○ Fernando Albornoz \& Antonio Cabrales, 2010. 'Fiscal Centralization and the Political Process,"Working Papers 2010-02, FEDEA. [Downloadable!]

- Facundo Albornoz \& Antonio Cabrales, 2010. "Fiscal Centralization and the Political Process," Discussion Papers 10-10, Department of Economics, University of Birmingham. [Downloadable!]

\section{Statistics}

Access and download statistics

Did you know? You too can volunteer for RePEc, for example by editing a NEP report.

This page was last updated on 2011-4-19. 
This information is provided to you by IDEAS at the Department of Economics, College of Liberal Arts and Sciences, University of Connecticut using RePEc data on a server sponsored by the Society for Economic Dynamics. 


\section{American Economic Journal}

From Wikipedia, the free encyclopedia

The American Economic Journal is a group of four peer-reviewed academic journals published by the American Economic Association. The names of the individual journals consist of the prefix American Economic Journal with a descriptor of the field attached. The four field journals which started in 2009 are Applied Economics, Economic Policy, Macroeconomics, and Microeconomics.

\section{Contents}

- 1 History

- 2 American Economic Journal: Applied Economics

- 3 American Economic Journal: Economic Policy

- 4 American Economic Journal: Macroeconomics

- 5 American Economic Journal: Microeconomics

- 6 References

- 7 External links

\section{History}

The American Economic Association set up an ad hoc Committee on Journals chaired by Robert Hall which in April 2006, after a three-year study of the subject, recommended that the American Economic Association (AEA) start four new field journals. One of the reasons given was that almost all other academic societies publish more than three journals, and that by adding more journals, the diversity of editors would be increased. ${ }^{[1]}$ Other reasons included the elevated pricing of field journals in economics, most of which are published by Elsevier, and the inability of The American Economic Review to deal with the large number of submissions it received. ${ }^{[2]}$

The recommendation to publish the four new journals was approved by the Executive Committee of the AEA in 2006 and the publication start date was set in 2009. The president of the AEA at the time, George Akerlof, appointed a search committees for the editors of the new journals.

Although all four journals have a quarterly frequency, the American Economic Journal: Applied Economics was the only one to have four issues in 2009, its first year of publication. The other three journals had two issues in 2009 and plan to move to four in 2010 .

\section{American Economic Journal: Applied Economics}

This journal publishes papers covering in applied economics, primarily on empirical microeconomic issues. Fields for this journal include labor economics, development microeconomics, health economics, education, demography, empirical corporate finance, empirical international trade, and empirical behavioral economics. This journal has established an online discussion forum at which published articles can be commented on. Esther Duflo was chosen as the first editor.

\section{American Economic Journal}

$\begin{array}{ll}\begin{array}{l}\text { Abbreviated } \\ \text { title (ISO) }\end{array} & \text { Am. Econ. } J . \\ \text { Discipline } & \text { Economics } \\ \text { Language } & \text { English }\end{array}$

Publication details

Publisher American Economic Association (United States)

Publication 2009-present

history

Frequency

Quarterly

\section{Indexing}

ISSN

AEJ: Applied Economics
1945-7782
(http://www.worldcat.org
/issn/1945-7782) (print)
1945-7790
(http://www.worldcat.org
/issn/1945-7790) (web)
AEJ: Economic Policy
1945-7731
(http://www.worldcat.org
/issn/1945-7731) (print)
1945-774x
(http://www.worldcat.org
/issn/1945-774x) (web)
AEJ: Macroeconomics
1945-7707
(http://www.worldcat.org
/issn/1945-7707) (print)
1945-7715
(http://www.worldcat.org
/issn/1945-7715) (web)
AEJ: Microeconomics
1945-7669
(http://www.worldcat.org
/issn/1945-7669) (print)
1945-7685
(http://www.worldcat.org
/issn/1945-7685) (web)

Links

\section{American Economic Journal: Economic Policy}

- Journal homepage (http://www.aeaweb.org /aea_journals.php) 
This journal publishes papers dealing with economic policy and its role in economic outcomes. Fields that may find an outlet in this journal include public economics, urban economics, health economics, education, welfare and political institutions, law and economics, economic regulation, and environmental economics. Alan Auerbach was chosen as the first editor.

\section{American Economic Journal: Macroeconomics}

This journal publishes papers on macroeconomics, including aggregate fluctuations and growth, and policy related to these fields. Fields that may find an outlet in this journal include monetary theory, industrial organization, finance, labor economics, political economy, public finance, international economics, and development economics.

Olivier Blanchard was chosen as the first editor. He resigned in 2009 stating that his duties as Chief Economist of the International Monetary Fund proved incompatible with editing the journal in the context of the current financial crisis. ${ }^{[3]} \mathrm{He}$ was replaced by Steven J. Davis.

\section{American Economic Journal: Microeconomics}

This journal publishes papers on microeconomic theory. Fields that may find an outlet in this journal include industrial organization, international trade, political economy, and finance. Andrew Postlewaite was chosen as the first editor.

\section{References}

1. ^ Announcement statement of the new journals, accessed on 31 August 2009 (http://www.vanderbilt.edu/AEA/new_journals.htm)

2. ^ David Glenn. "American Economic Association Plans 4 New Journals". The Chronicle of Higher Education. January 25, 2008. Available online at http://chronicle.com/article/American-Economic-Association/440

3. ^ Olivier Blanchard. "Report of the Editor. American Economic Journal: Macroeconomics", American Economic Review: Papers \& Proceedings, 2009, 99:2, 681-682, doi:10.1257/aer.99.2.681.

\section{External links}

- AEJ: Applied Economics (http://www.aeaweb.org/aej-applied/index.php)

- AEJ: Economic Policy (http://www.aeaweb.org/aej-policy/index.php)

- AEJ: Macroeconomics (http://www.aeaweb.org/aej-macro/index.php)

- AEJ: Microeconomics (http://www.aeaweb.org/aej-micro/index.php)

Retrieved from "http://en.wikipedia.org/wiki/American_Economic_Journal" Categories: Economics journals | Publications established in 2009|English-language journals | Quarterly journals

- This page was last modified on 1 April 2011 at 17:33.

- Text is available under the Creative Commons Attribution-ShareAlike License; additional terms may apply. See Terms of Use for details.

Wikipedia ${ }^{\circledR}$ is a registered trademark of the Wikimedia Foundation, Inc., a non-profit organization. 